Article

\title{
Investigation of Ion Transport Parameters and Electrochemical Performance of Plasticized Biocompatible Chitosan-Based Proton Conducting Polymer Composite Electrolytes
}

\author{
Jihad M. Hadi ${ }^{1} \oplus$, Shujahadeen B. Aziz ${ }^{2,3, *}$, Salah R. Saeed ${ }^{4}$, Mohamad A. Brza ${ }^{2,5}$, \\ Rebar T. Abdulwahid $\left.{ }^{2,6}{ }^{(}\right)$, Muhamad H. Hamsan ${ }^{7}$, Ranjdar M. Abdullah ${ }^{2}$, Mohd F. Z. Kadir ${ }^{7}$ \\ and S. K. Muzakir ${ }^{8}$ (i) \\ 1 Department of Medical Laboratory of Science, College of Health Sciences, University of Human Development, \\ Kurdistan Regional Government, Sulaimani 46001, Iraq; jihad.chemist@gmail.com \\ 2 Hameed Majid Advanced Polymeric Materials Research Lab., Department of Physics, College of Science, \\ University of Sulaimani, Qlyasan Street, Sulaimani 46001, Iraq; mohamad.brza@gmail.com (M.A.B.); \\ rebar.abdulwahid@univsul.edu.iq (R.T.A.); ranjdar.abdullah@univsul.edu.iq (R.M.A.) \\ 3 Department of Civil Engineering, College of Engineering, Komar University of Science and Technology, \\ Sulaimani 46001, Iraq \\ 4 Charmo Research Center, Charmo University, Peshawa Street, Chamchamal, Sulaimani 46023, Iraq; \\ salah.saeed@charmouniversity.org \\ 5 Department of Manufacturing and Materials Engineering, Faculty of Engineering, \\ International Islamic University of Malaysia, Kuala Lumpur 53100, Malaysia \\ 6 Department of Physics, College of Education, Old Campus, University of Sulaimani, \\ Kurdistan Regional Government, Sulaimani 46001, Iraq \\ 7 Centre for Foundation Studies in Science, University of Malaya, Kuala Lumpur 50603, Malaysia; \\ hafizhamsan93@gmail.com (M.H.H.); mfzkadir@um.edu.my (M.F.Z.K.) \\ 8 Material Technology Program, Faculty of Industrial Sciences \& Technology, Universiti Malaysia Pahang, \\ Lebuhraya Tun Razak, Gambang, Kuantan 43600, Malaysia; saifful@ump.edu.my \\ * Correspondence: shujahadeenaziz@gmail.com
}

Received: 26 October 2020; Accepted: 17 November 2020; Published: 21 November 2020

\begin{abstract}
In this study, biopolymer composite electrolytes based on chitosan:ammonium iodide: $\mathrm{Zn}(\mathrm{II})$-complex plasticized with glycerol were successfully prepared using the solution casting technique. Various electrical and electrochemical parameters of the biopolymer composite electrolytes' films were evaluated prior to device application. The highest conducting plasticized membrane was found to have a conductivity of $1.17 \times 10^{-4} \mathrm{~S} / \mathrm{cm}$. It is shown that the number density, mobility, and diffusion coefficient of cations and anions fractions are increased with the glycerol amount. Field emission scanning electron microscope and Fourier transform infrared spectroscopy techniques are used to study the morphology and structure of the films. The non-Debye type of relaxation process was confirmed from the peak appearance of the dielectric relaxation study. The obtained transference number of ions (cations and anions) and electrons for the highest conducting sample were identified to be 0.98 and 0.02 , respectively. Linear sweep voltammetry shows that the electrochemical stability of the highest conducting plasticized system is $1.37 \mathrm{~V}$. The cyclic voltammetry response displayed no redox reaction peaks over its entire potential range. It was discovered that the addition of $\mathrm{Zn}$ (II)-complex and glycerol plasticizer improved the electric double-layer capacitor device performances. Numerous crucial parameters of the electric double-layer capacitor device were obtained from the charge-discharge profile. The prepared electric double-layer capacitor device showed that the initial values of specific capacitance, equivalence series resistance, energy density, and power density are $36 \mathrm{~F} / \mathrm{g}, 177 \Omega, 4.1 \mathrm{Wh} / \mathrm{kg}$, and $480 \mathrm{~W} / \mathrm{kg}$, respectively.
\end{abstract}


Keywords: solid polymer electrolyte; electrochemical impedance spectroscopy; ion transport parameters; TNM and LSV measurement; EDLC device

\section{Introduction}

Polymer electrolytes with $\mathrm{H}^{+}$(or proton) as a charge carrier species were used in electrochemical energy storage device application [1,2]. Polymers offer a wide variety of applications, and their industry has grown more rapidly compared to other classes of materials. Among their applications, solid polymer electrolyte (SPE) has been extensively investigated. Essentially, it can be formed through dissolving inorganic salts in a polymer matrix comprising heteroatoms like $\mathrm{O}, \mathrm{N}, \mathrm{S}$, and so on [3-5]. Chitosan (CS) has received a great deal of attention by means of a natural polymer due to its noteworthy advantages, including biodegradability, biocompatibility, safety, electrolytic characteristics, and high chemical resistance [6]. Also, CS backbone structure possesses multifunctional properties (i.e., $\mathrm{OH}$ and $\mathrm{NH}_{2}$ ), and the protonated amino group makes it capable of forming a high conductivity of the polymer electrolyte system [7]. The amine group $\left(\mathrm{NH}_{2}\right)$ in the structure can act as an electron donor to interact with the inorganic salts. The nitrogen atom acts as a complexation site for the coordination of cations. The interaction between the inorganic salts with the CS leads to improvement of the amorphous structure [8]. The conductivity of ions is the dominant property of a polymer electrolyte and is improved by enhancing the amorphous nature. Because of these features, CS has the potential to be used in the application of energy storage devices like a host polymeric material, which in turn reduces environmental pollutions [9].

Polymer electrolytes offer a wide variety of applications in energy storage devices. The polymer electrolytes can be used for application in fuel cells. Polymer electrolyte fuel cell is of interest as a power source in vehicle and portable application owing to its eco-friendly and high energy efficiency [10]. Supercapacitors (SCs) are also a class of electrochemical energy storage devices considered as promising energy conversion devices for an extensive variety of applications. SCs are used in various applications, where the necessity is to store or release large quantities of energy in a little amount of time. Currently, the SCs are used mainly in electric vehicles, hybrid electric vehicles, and fuel cell vehicles like trains, passenger cars, and trolleybuses. Another field of SCs' application are electronic devices such as volatile memory backups and uninterruptible power supplies. Another field of application are solar arrays or wind turbines, energy harvesting systems, where SCs have a supplementary role next to traditional batteries [11,12]. SCs are generally classified into pseudocapacitor (PC) and electrical double-layer capacitor (EDLC), which depends on their charge storage mechanisms $[13,14]$. EDLC consists of a couple of polarized porous electrodes and does not experience Faradaic reactions across the operating range of potential [15]. The EDLC function depends on the phenomenon involving forming an electrical double-layer at the interfaces between the electrolyte sample and electrodes [16]. In addition, through using the EDLCs, the device can be charged and discharged quickly within a few seconds, which is attributed to its storage mechanism [17].

Ali et al. [18] fabricated carbon nanospheres (NSs) using lablab purpureus seeds and they showed that the carbon NSs materials are useful in SCs electrode applications. The literature shows that various forms of carbons have been used as electrodes in fabricating of EDLCs owing to its excellent thermal and chemical stability with its abundance, including graphite, carbon nanotubes, carbon aerogel, and activated carbon [19-21]. On the other hand, the properties of the activated carbons (ACs) used as an active material greatly influence the performances of EDLCs, for instance, size and shape of pores, electrical conductivity, as well as surface functional groups [22,23]. However, the AC has been widely discovered for commercial EDLCs as a result of providing high values of capacitance due to its high microporosity [24].

Meanwhile, using the zinc metal complex ( $\mathrm{Zn}(\mathrm{II})$-complex) in the preparation of biodegradable polymer-based electrolytes contributes to improve the amorphous phase, which is promising for the 
ionic conduction mechanism. Asnawi et al. [25] showed that the addition of the $\mathrm{Zn}$ (II)-complex into the CS polymer electrolyte improved the EDLC device performance. The authors showed that the addition of $\mathrm{Zn}$ (II)-complex into the CS-based electrolyte improved an amorphous phase for ion conduction. Brza et al. [26,27] indicated that the inclusion of Ce(III)-complex into Poly(vinyl alcohol) (PVA) polymer electrolyte improved the amorphous phase and the performance of the EDLC device. The authors also indicated that the Ce(III)-complex improved the transport parameters of diffusion coefficient $(D)$, charge carrier density $(n)$, and mobility $(\mu)$ of cations and anions due to the enhancement of the amorphous phase [26,27].

Due to the presence of multi-hydroxyl groups $(\mathrm{OH})$ in its structure, glycerol was used as an adequate plasticizer to improve conductivity. Low lattice energy, large size of anion, and small size of cation have decided the option of the metal salts. It has been established that ammonium salts possess good thermal stability and high ionic conductivity. Through doping with ammonium iodide $\left(\mathrm{NH}_{4} \mathrm{I}\right)$, and using glycerol plasticizer, the local viscosity of the polymer electrolyte matrix is reduced, thus promoting the mobility of ions (i.e., $\mathrm{NH}_{4}^{+}$), which in turn increases the electrical conductivity $[6,16,28]$. In this paper, various electrical and electrochemical performances of CS-based polymer composite electrolytes (PCEs) have been investigated. The glycerol plasticizer further improved the amorphous phase and dissociates the extra ions to enhance the electrical conductivity. Thus, it is reasonable to use the relatively high conductance of the glycerolized CS: $\mathrm{NH}_{4} \mathrm{I}: \mathrm{Zn}$ (II)-metal complex based-(PCEs) system as the electrode separator for fabricating the EDLC.

\section{Materials and Methods}

\subsection{Materials}

In this study, CS with the average molecular weight of $35,000 \mathrm{~g} / \mathrm{mol}$ has been used as a polymer material. Other raw materials, including ammonium iodide $\left(\mathrm{NH}_{4} \mathrm{I}\right)$ as a doping salt, acetic acid $\left(\mathrm{CH}_{3} \mathrm{COOH}\right)$ as a solvent, and glycerol $\left(\mathrm{C}_{3} \mathrm{H}_{8} \mathrm{O}_{3}\right)$ as a plasticizer, were used to fabricate plasticized systems. All the chemicals were supplied by Sigma-Aldrich (Kuala Lumpur, Malaysia) without being purified.

\subsection{Electrolyte Preparation}

The preparation of the glycerolized CS: $\mathrm{NH}_{4} \mathrm{I}: \mathrm{Zn}$ (II)-complex system involves the following procedure. At the beginning, $1 \mathrm{~g}$ of CS was dissolved into $50 \mathrm{~mL}$ acetic acid (1\%) solution for around $3 \mathrm{~h}$. Then, $40 \mathrm{wt} . \%$ fixed quantity of the ammonium iodide $\left(\mathrm{NH}_{4} \mathrm{I}\right)$ was added into the above mixture. The solution was stirred continuously at room temperature with a magnetic stirrer until a homogenous mixture was formed. After that, a fixed amount of $10 \mathrm{~mL}$ of $\mathrm{Zn}(\mathrm{II})$-complex was added into the solution. The same procedure is used to fabricate $\mathrm{Zn}$ (II)-complex as indicated in our previous study, in the Materials and Methods Section in Reference [29]. Subsequently, glycerol with different concentration was added to the $\mathrm{CS}: \mathrm{NH}_{4} \mathrm{I}: \mathrm{Zn}$ (II)-complex and constantly stirred until a homogenous solution appeared. The glycerol concentrations were added and changed from 0 to $30 \mathrm{wt} . \%$. The prepared samples were labeled as CSNZG0, CSNZG1, CSNZG2, and CSNZG3 for CS:NH $4 \mathrm{I}: Z n(I I)$-complex filled with 0, 10, 20, and $30 \mathrm{wt} . \%$ of glycerol, respectively. Lastly, the solutions were poured into Petri dishes and covered with filter paper to avoid any contamination. The Petri dishes were left untouched to evaporate the solvent eventually so as to attain dry films. Table 1 summarizes the composition and designation of PCE samples. 
Table 1. The composition and designation of glycerolized CS: $\mathrm{NH}_{4} \mathrm{I}: \mathrm{Zn}(\mathrm{II})$-complex systems.

\begin{tabular}{ccccc}
\hline $\begin{array}{c}\text { Sample } \\
\text { Designation }\end{array}$ & $\begin{array}{c}\text { Wt. (g) } \\
\text { CS }\end{array}$ & $\begin{array}{c}\text { Wt. } \% \\
\mathbf{N H}_{\mathbf{4}} \mathbf{I}\end{array}$ & $\begin{array}{c}\text { Zn (II)-Complex } \\
(\mathbf{m L})\end{array}$ & $\begin{array}{c}\text { Wt. } \% \\
\text { Glycerol }\end{array}$ \\
\hline CSNZG0 & 1 & 40 & 10 & 0 \\
CSNZG1 & 1 & 40 & 10 & 10 \\
CSNZG2 & 1 & 40 & 10 & 20 \\
CSNZG3 & 1 & 40 & 10 & 30 \\
\hline
\end{tabular}

\subsection{Electrochemical Impedance Spectroscopy (EIS) Analysis}

The data processing of impedance measurement was carried out at room temperature using a LCR meter (HIOKI 3531 Z Hi-tester, Nagano, Japan). The range of frequency was measured between $(50 \mathrm{~Hz} \leq f \leq 5 \mathrm{MHz})$. The synthesized films were placed between two stainless-steel (SS) electrodes after the films were cut into circles with diameter of $2 \mathrm{~cm}$ under spring pressure. To measure the real $\left(Z^{\prime}\right)$ and imaginary $\left(Z^{\prime \prime}\right)$ parts of complex impedance spectroscopy $\left(Z^{*}\right)$, the cell was connected to a computer software.

\subsection{Field Emission Scanning Electron Microscopy (FESEM) and Fourier Transform Infrared Spectroscopy (FTIR) Study}

Field emission scanning electron microscopy (FESEM) was performed using a Hitachi SU8220 (Hitachi, Tokyo, Japan) at 500 $\times$ magnification. The samples' morphology was studied by the FESEM images. The films were analyzed using a Fourier Transform Infrared (FTIR) Spectrophotometer (Thermo Scientific, Nicolet iS10, Ashford, UK) that was fixed in the wavenumber range between 450 and $4000 \mathrm{~cm}^{-1}$ and having $2 \mathrm{~cm}^{-1}$ resolution.

\subsection{Transfer Number Measurement (TNM) and Linear Sweep Voltammetry (LSV) Analysis}

The V \& A instrument DP3003 digital direct current (DC) power supply has been employed to obtain the cation and anion transference number $\left(t_{i o n}\right)$ and electronic transference number $\left(t_{e l}\right)$ using the DC polarization method. The highest conducting composite electrolyte (i.e., CSNZG3) was kept between a pair of analogous stainless-steel (SS) blocking electrodes. A constant operating potential of $0.2 \mathrm{~V}$ was applied, and the cell was polarized at ambient temperature. To observe the highest operating voltage of the CSNZG3 system, the linear sweep voltammetry (LSV) has been done using a Digi-IVY DY2300 potentiostat. The LSV was measured at a scan rate of $10 \mathrm{mV} / \mathrm{s}$ in the voltage range from 0 to $2.5 \mathrm{~V}$. The cell arrangement was the same as the TNM arrangements.

\subsection{Fabricating EDLC}

The creation of the EDLC electrodes comprises four consecutive stages. The first stage involves a dry mixing procedure, in which $3.25 \mathrm{~g}$ of activated carbon (AC) is mixed with $0.25 \mathrm{~g}$ of carbon black (CB) at $500 \mathrm{rpm}$ for about $20 \mathrm{~min}$. Additionally, $0.5 \mathrm{~g}$ of polyvinylidene fluoride (PVdF) is added to the $15 \mathrm{~mL} \mathrm{~N}$-methyl pyrrolidone (NMP) solvent and mixed for around $60 \mathrm{~min}$. The second stage was to dissolve AC-CB powder into a PVdF-NMP solution using a binder until a dark black solution appeared. The third stage is the coating of the produced black thick solution into an aluminum foil using a doctor blade. In the fourth stage, the coated aluminum foil was then dried in an oven $\left(\sim 60^{\circ} \mathrm{C}\right)$ for several hours. Subsequently, the electrodes were located in a silica gel desiccator to eliminate extra moisture. Also, the electrodes were cut with an area of $2.01 \mathrm{~cm}^{2}$. The cell arrangement of the EDLC was performed by placing the highest conducting sample between two activated carbon electrodes. Then, the CR2022 coin cell was used to pack the electrolyte cell in a case of Teflon. To evaluate the energy storage mechanism, the preliminary test for the fabricated EDLC was performed at ambient temperature via cyclic voltammetry (CV). A Digi-IVY DY2300 potentiostat was employed at the 
different sweep rates in the potential range from 0 to $0.9 \mathrm{~V}$. The EDLC charge-discharge profile was investigated using the Newer battery cycler at a current density of $0.5 \mathrm{~mA} / \mathrm{cm}^{2}$.

\section{Results and Discussion}

\subsection{Impedance Spectroscopy}

Electrical impedance spectroscopy (EIS) is a familiar approach in electrochemistry for measuring both bulk transport behavior and electrochemical reactions on its superficial material [30]. It is a powerful technique to recognize the effect of different layers of polymers, chemicals, and composite electrodes. Its measurements will cover the key parameters of an electrochemical system, such as a change in current density, charge transfer resistance, as well as double-layer capacitances. Furthermore, the surface roughness and porosity of an electrode can also be evaluated using EIS [31]. The impedance spectra $\left(Z_{i}\right.$ versus $\left.Z_{r}\right)$ of the CSNZG0, CSNZG1, CSNZG2, and CSNZG3 composite electrolyte samples at room temperature are shown in Figure $1 \mathrm{a}-\mathrm{d}$. The normal finding for the EIS studies in polymer electrolytes usually involves two distinct regions: namely a spike and a semicircle at the region of low and high frequency, respectively. The high-frequency semicircle results from the conduction process in the bulk polymer composite electrolytes and it is represented by a parallel combination of bulk capacitance and bulk resistance. Whereas, the low-frequency spike characterizes the electrical double-layer capacitance at the blocking electrodes [32]. The charge accumulation at the region of the sample/electrode interfaces creates EDLC. One may notice that the impedance plots display a straight line at the low-frequency region which is due to electrode polarization (EP) [33,34]. One can obtain the bulk resistance of the electrolyte $\left(R_{b}\right)$ values due to the point from the straight line intercepts on the $Z_{r}$-axis of impedance plots. Correspondingly, the following formula was used to calculate the ionic conductivity $\left(\sigma_{d c}\right)$ of the composite polymer electrolytes [35]:

$$
\sigma_{d c}=\left(\frac{1}{R_{b}}\right) \times\left(\frac{t}{A}\right)
$$

where $t$ is the sample thickness, and $A$ is the area of the electrolyte sample. It is noteworthy that the $R_{b}$ value was decreased with increasing of the glycerol concentrations and reached its minimum values at $30 \mathrm{wt} . \%$ of glycerol content (see Figure 1a-d) [36]. Earlier studies on different polymer electrolytes have shown that the DC conductivity was improved up to two orders using the glycerol plasticizer $[4,16,21,37]$. The DC ionic conductivity was determined and presented in Table 2 . It was found that the electrolyte sample incorporated with $30 \mathrm{wt} . \%$ of glycerol displayed the highest ionic conductivity of $1.17 \times 10^{-4} \mathrm{~S} / \mathrm{cm}$. Osman et al. [38] have attained the room temperature ionic conductivity of $4 \times 10^{-5} \mathrm{~S} / \mathrm{cm}$ using the $\mathrm{CS}-\mathrm{LiCF}_{3} \mathrm{SO}_{3}$-ethylene carbonate (EC) system. Leones et al. [39] documented a result for the system of CS-glycerol incorporated with cyano-based ionic liquids. Ali et al. [40] fabricated porous nanocarbons (NCs) using bio-waste oil palm leaves. The porous carbon nanoparticles (NPs) showed superior supercapacitance (SPs) properties. Low resistance values were achieved in their study via fitting the impedance spectra representing the availability of these porous NCs as a precursor in the SCs electrode fabrication. Ali et al. [41] in another study fabricated porous carbon NPS with very high SPs value. Impedance spectra showed low resistance values of these materials, indicating their suitability for application in SCs electrodes. 

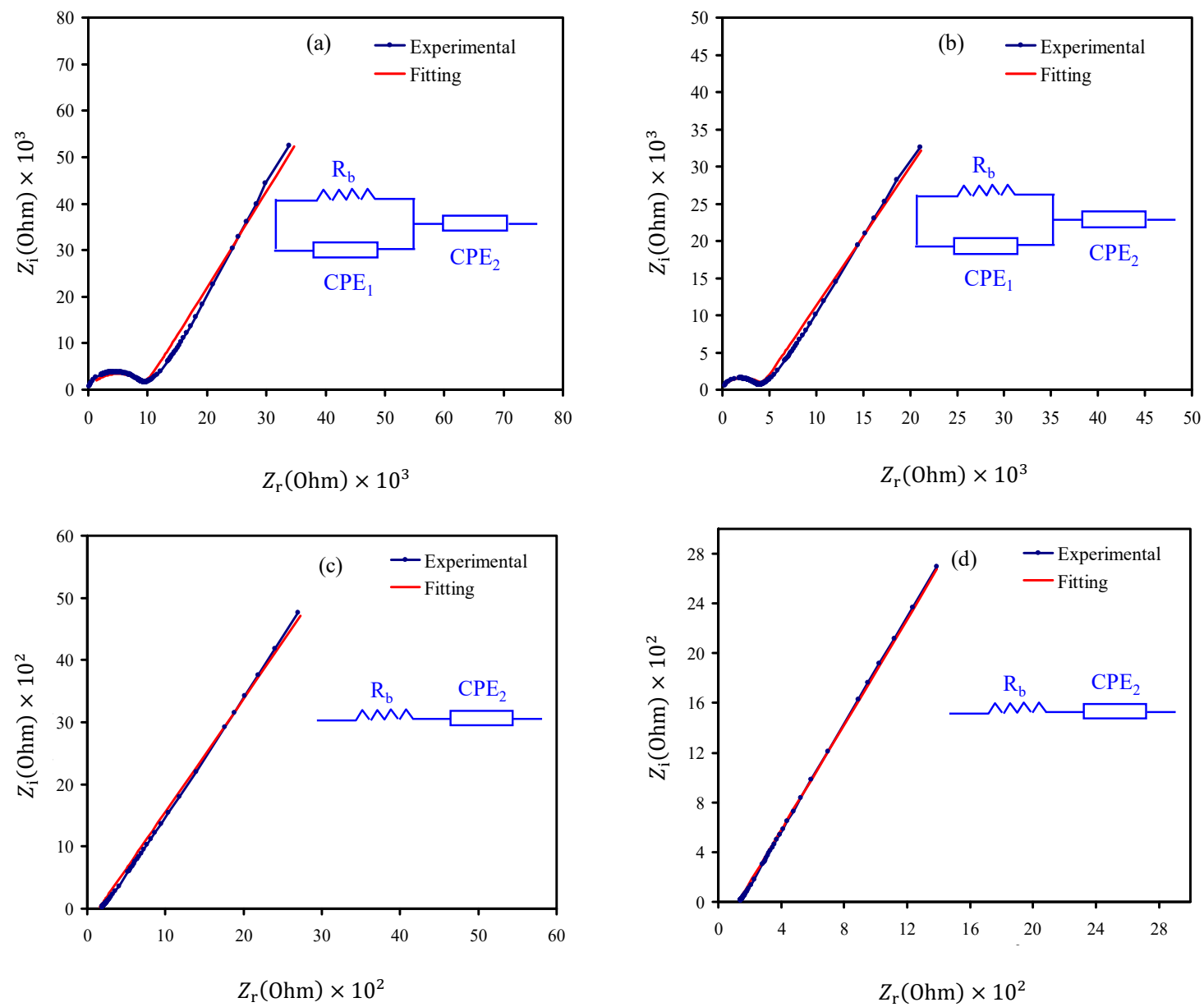

Figure 1. EIS plots for (a) CSNZG0, (b) CSNZG1, (c) CSNZG2, and (d) CSNZG3 electrolyte films.

Table 2. DC ionic conductivity $\left(\sigma_{d c}\right)$ of the un-plasticized and plasticized CS: $\mathrm{NH}_{4} \mathrm{I}: \mathrm{Zn}$ (II)-complex system at room temperature.

\begin{tabular}{cc}
\hline Sample Code & Ionic Conductivity $\left(\sigma_{d c}\right)\left(\mathbf{S} . \mathbf{c m}^{-\mathbf{1}}\right)$ \\
\hline CSNZG0 & $1.56 \times 10^{-6}$ \\
CSNZG1 & $3.68 \times 10^{-6}$ \\
CSNZG2 & $1.01 \times 10^{-4}$ \\
CSNZG3 & $1.17 \times 10^{-4}$ \\
\hline
\end{tabular}

The electrical equivalent circuit (EEC) model is used in the study of impedance spectroscopy as the EEC model is quick and provides an entire picture of the systems [26]. The EIS plots are interpreted in terms of the EEC including $R_{b}$ for the charge carriers in the samples and two constant phase elements (CPEs), which are CPE1 and CPE2, as shown in the inset of Figure 1a-d. The high-frequency region shows the $R_{b}$ and CPE1 connection in parallel, whereas the low-frequency region shows CPE2, i.e., the formed double-layer capacitance between the SPE and electrodes. The impedance of CPE $\left(Z_{C P E}\right)$ is expressed as [26]:

$$
Z_{C P E}=\frac{1}{C \omega^{p}}\left[\cos \left(\frac{\pi p}{2}\right)-i \sin \left(\frac{\pi p}{2}\right)\right]
$$


In Equation (2), $C$ is the CPE capacitance, $\omega$ is the angular frequency, and $P$ relates to the deviation of the vertical axis of the impedance plots. The real part $\left(Z_{r}\right)$ and imaginary part $\left(Z_{i}\right)$ of complex impedance $\left(Z^{*}\right)$ related with the EEC (inset of Figure $\left.1 a, b\right)$ are expressed as:

$$
Z_{r}=\frac{R_{b}{ }^{2}(Z 1)+R_{b}}{2 R_{b}(Z 1)+R_{b}^{2} C_{1}^{2} \omega^{2 p 1}+1}+\frac{Z 2}{C_{2} \omega^{p 2}}
$$

where, $\mathrm{Z} 1=C_{1} \omega^{p 1} \cos \left(\frac{\pi p_{1}}{2}\right)$ and $\mathrm{Z} 2=\cos \left(\frac{\pi p_{2}}{2}\right)$

$$
Z_{i}=\frac{R_{b}^{2}(Z 3)}{2 R_{b}(A 1)+R_{b}^{2} C_{1}^{2} \omega^{2 P 1}+1}+\frac{Z 4}{C_{2} \omega^{p 2}}
$$

where, $\mathrm{Z} 3=C_{1} \omega^{p 1} \sin \left(\frac{\pi p_{1}}{2}\right)$ and $\mathrm{Z} 4=\sin \left(\frac{\pi p_{2}}{2}\right)$

All the circuit element parameters that are used for impedance plots' fitting for all the samples are shown in Table 3. In the Cole-Cole plots, at higher glycerol concentration (Figure 1c,d), the semicircle disappeared, indicating that only the resistive component of the electrolyte systems exists [26]. The disappearance of the semicircle in the CSNZG2 and CSNZG3 systems is because most of the cations and anions in the bulk of the electrolyte move in opposite directions toward the electrodes to form the double layer. In such case, the $Z_{r}$ and $Z_{i}$ associated to the EEC are expressed as:

$$
\begin{gathered}
Z_{r}=R+\frac{Z 2}{C_{2} \omega^{p 2}} \\
Z_{i}=\frac{Z 4}{C_{2} \omega^{p 2}}
\end{gathered}
$$

Table 3. The EEC fitting parameters for the plasticized systems at room temperature.

\begin{tabular}{ccccc}
\hline Sample & $\boldsymbol{K}_{\mathbf{1}}\left(\boldsymbol{F}^{-\mathbf{1}}\right)$ & $\boldsymbol{K}_{\mathbf{2}}\left(\boldsymbol{F}^{-\mathbf{1}}\right)$ & $\boldsymbol{C}_{\mathbf{1}}(\boldsymbol{F})$ & $\boldsymbol{C}_{\mathbf{2}}(\boldsymbol{F})$ \\
\hline CSNZG0 & $4.6 \times 10^{8}$ & $3.5 \times 10^{6}$ & $2.17 \times 10^{-9}$ & $2.86 \times 10^{-7}$ \\
CSNZG1 & $4.5 \times 10^{8}$ & $1.90 \times 10^{6}$ & $2.22 \times 10^{-9}$ & $5.26 \times 10^{-7}$ \\
CSNZG2 & - & $2.7 \times 10^{5}$ & - & $3.70 \times 10^{-6}$ \\
CSNZG3 & - & $1.85 \times 10^{5}$ & - & $5.41 \times 10^{-6}$ \\
\hline
\end{tabular}

As the (CSNZG0 and CSNZG1) impedance data consists of a spike/tail and a semicircle, the transport parameters of diffusion coefficient $(D)$, mobility $(\mu)$, and number density $(n)$ of cations and anions are computed by the equations below [26].

The $D$ of the cations and anions in CSNZG0 and CSNZG1 systems is computed by the relation,

$$
D=\left(\frac{\left(K_{2} \varepsilon_{o} \varepsilon_{r} A\right)^{2}}{\tau_{2}}\right)
$$

where $\varepsilon_{r}$ is the dielectric constant, $\varepsilon_{0}$ is the permittivity in vacuum, and $\tau_{2}$ is the reciprocal of angular frequency corresponding to the minimum in $Z_{i}$.

The mobility $(\mu)$ of the cations and anions is calculated via the relation below,

$$
\mu=\left(\frac{e D}{K_{b} T}\right)
$$

where $T$ is the absolute temperature and $k_{b}$ is the Boltzmann constant.

Since conductivity $\left(\sigma_{D C}\right)$ is shown by

$$
\sigma_{D c}=n e \mu,
$$


so, the number density of the cations and anions $(n)$ is computed using Equation (10):

$$
n=\left(\frac{\sigma_{d c} K_{b} T \tau_{2}}{\left(e K_{2} \varepsilon_{o} \varepsilon_{r} A\right)^{2}}\right)
$$

As the impedance data of CSNZG2 and CSNZG3 consists of a spike, the $D$ is calculated by Equation (11) [26]:

$$
D=D \circ \exp \left\{-0.0297[\ln D \circ]^{2}-1.4348 \ln D \circ-14.504\right\}
$$

where

$$
D \circ=\left(\frac{4 k^{2} l^{2}}{R_{b}{ }^{4} \omega 3_{\min }}\right)
$$

where $l$ is the electrolyte thickness, and $\omega_{\min }$ is the angular frequency corresponding to the minimum $Z_{i}$. Table 4 shows the cation and anion transport parameters and the $\omega_{\min }$ values for the electrolyte system.

Table 4. The $\omega, D, \mu$, and $n$ values at room temperature.

\begin{tabular}{ccccc}
\hline Sample & $\boldsymbol{\omega}\left(\mathbf{r a d ~ s} \mathbf{~}^{-\mathbf{1}}\right)$ & $\boldsymbol{D}\left(\mathbf{c m}^{\mathbf{2}} \mathbf{s}^{-\mathbf{1}}\right)$ & $\boldsymbol{\mu}\left(\mathbf{c m}^{\mathbf{2}} \mathbf{V}^{-\mathbf{1}} \mathbf{s}\right)$ & $\boldsymbol{n} \mathbf{( \mathbf { c m } ^ { - 3 } )}$ \\
\hline CSNZG0 & $3.39 \times 10^{5}$ & $4.13 \times 10^{-8}$ & $1.60 \times 10^{-6}$ & $6.06 \times 10^{18}$ \\
CSNZG1 & $2.01 \times 10^{6}$ & $7.73 \times 10^{-8}$ & $3.01 \times 10^{-6}$ & $7.63 \times 10^{18}$ \\
CSNZG2 & $6.28 \times 10^{4}$ & $3.65 \times 10^{-7}$ & $1.42 \times 10^{-5}$ & $4.43 \times 10^{19}$ \\
CSNZG3 & $6.16 \times 10^{5}$ & $3.89 \times 10^{-7}$ & $1.52 \times 10^{-5}$ & $4.81 \times 10^{19}$ \\
\hline
\end{tabular}

Based on Table 4, the value of $D$ is observed to increase as the glycerol concentration increases from 10 to $30 \mathrm{wt} . \%$. A similar trend is shown by $\mu$ as indicated in Table 4 where $\mu$ increases. The increase of $\mu$ and $D$ is ascribed to the enhancement of chain flexibility with the glycerol existence [26]. When the glycerol concentration is increased, the values of $D, \mu$, and $n$ are increased, which causes an increase in conductivity. This is because the more glycerol addition dissociates more salts to free cations and anions, thus increasing the number density of cations and anions [26].

The amorphous nature of polymer electrolyte is enhanced by adding salts into the polymer. The ionic conductivity and enhancement of amorphousity is associated to the greater mobility of ions and ions' diffusivity in the amorphous nature owing to the limited energy barrier. It was indicated in the earlier study [42] that the enhancement of the amorphous phase is valuable in local chain segmental movements, which will promote the movement of ions and thus, improve the conductivity of ions. It was also indicated in another study [43] that when the polymer film amorphous structure improves, there is an improvement in mobility of ions as larger free volume is provided in the polymer structure. This brings about an improvement in polymer chains' segmental motions owing to the increase in the flexibility of the polymer chains. Thus, there is an increase in the polymer electrolyte conductivity. The increase of DC conductivity with glycerol amount is rationalized by the presence of a percolating system for high plasticizer contents [5]. Figure 2 indicates the effect of plasticizer on the percolative behavior of the transport of ions. 


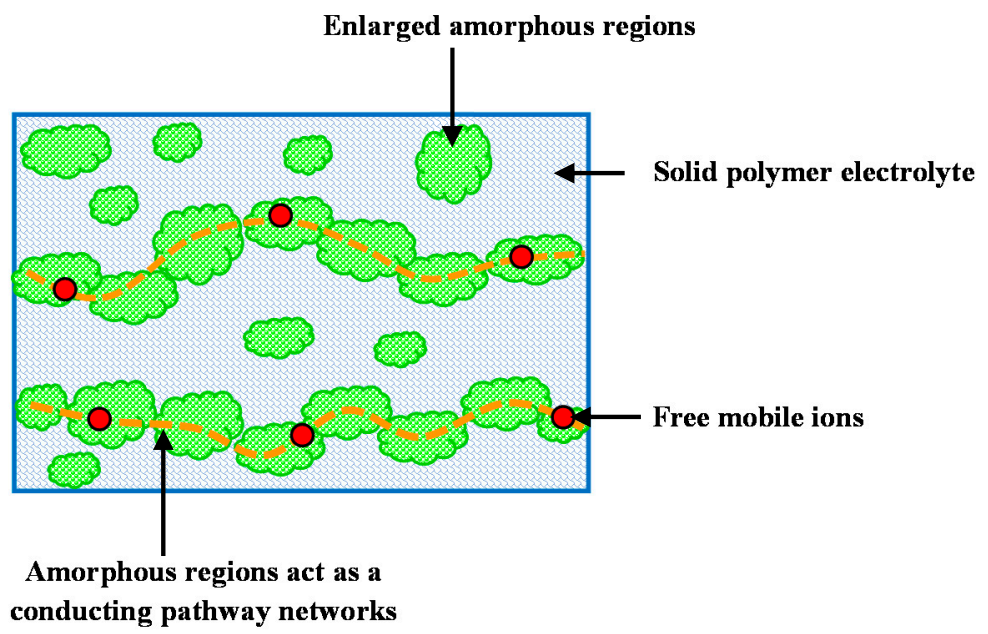

Figure 2. Percolative network of disordered regions produces rapid ion transport pathways for the mobile ions [5].

\subsection{Field Emission Scanning Electron Microscopy (FESEM) and Fourier Transform Infrared} Spectroscopy (FTIR)

Field emission scanning electron microscopy (FESEM) images were taken at $500 \times$ magnification for the films to support the EIS results. The FESEM for the films are indicated in Figure 3a-d. When there is incorporation of 10 and $20 \mathrm{wt} . \%$ glycerol into the electrolyte system, salts were protruded within the samples' surface, as indicated in Figure 3a,b. It is evident from the FESEM images that the protrude salts in the CSNZG3 system are not clearly observed as the concentration of glycerol increased to $30 \mathrm{wt} . \%$ in comparison with the other systems. The highest plasticized electrolyte system exhibits smooth and uniform surface morphology without any phase separation. The FESEM images are in good agreement with the EIS results. It is documented that the smooth morphology appearance is related to the improvement of the amorphous phase of the electrolyte system [44]. The smooth surface electrolytes will assist conducting ions to transfer easily, and therefore decrease the bulk resistance and increase the conductivity of ions [44].

The FTIR spectra for the plasticized electrolyte systems are shown in Figure 4a,b. From the outcomes achieved in this study, a strong peak was concentrated at about $2890 \mathrm{~cm}^{-1}$, which is associated to the $\mathrm{CH}$ stretching mode [45]. Though, it is seen that that the intensity of the peak is decreased with increasing glycerol amount. Another remark from the literature is that polymer chains comprising electronegative atoms ( $\mathrm{N}$ or $\mathrm{O}$ ) in the repeating units can serve as solvents for the salts [46]. This is indicated by the attractive reaction happening among the chains and the cations. Furthermore, it was indicated that chitosan is featured by a pair of hydroxyl groups $(\mathrm{OH})$ and a single amino group $\left(\mathrm{NH}_{2}\right)$ in each repeating units [47]. In a previous study [45], appearances of a wide peak at about $3359 \mathrm{~cm}^{-1}$ are ascribed to $-\mathrm{OH}$ stretching mode. The peak at about $1013-1060 \mathrm{~cm}^{-1}$ is related to $\mathrm{C}-\mathrm{O}-\mathrm{C}$ stretching modes [45]. As evidence, both peak shifting and change in intensity produce robust evidence about the complex creation among the dopant and the polymer. Each film is characterized by the key features of absorption peaks, such as change of $\mathrm{O}=\mathrm{C}-\mathrm{NHR}, \mathrm{NH}_{2}$, and $\mathrm{OH}$ groups of $\mathrm{CS}$ [45]. From Figure 4, it is obvious that shifts happen in the direction of the lower wave numbers in the bands of $\mathrm{O}=\mathrm{C}-\mathrm{NHR}, \mathrm{NH}_{2}$, and $\mathrm{OH}$ groups. This creates more understanding into the complex formation among the electrolyte components and the polymer. 

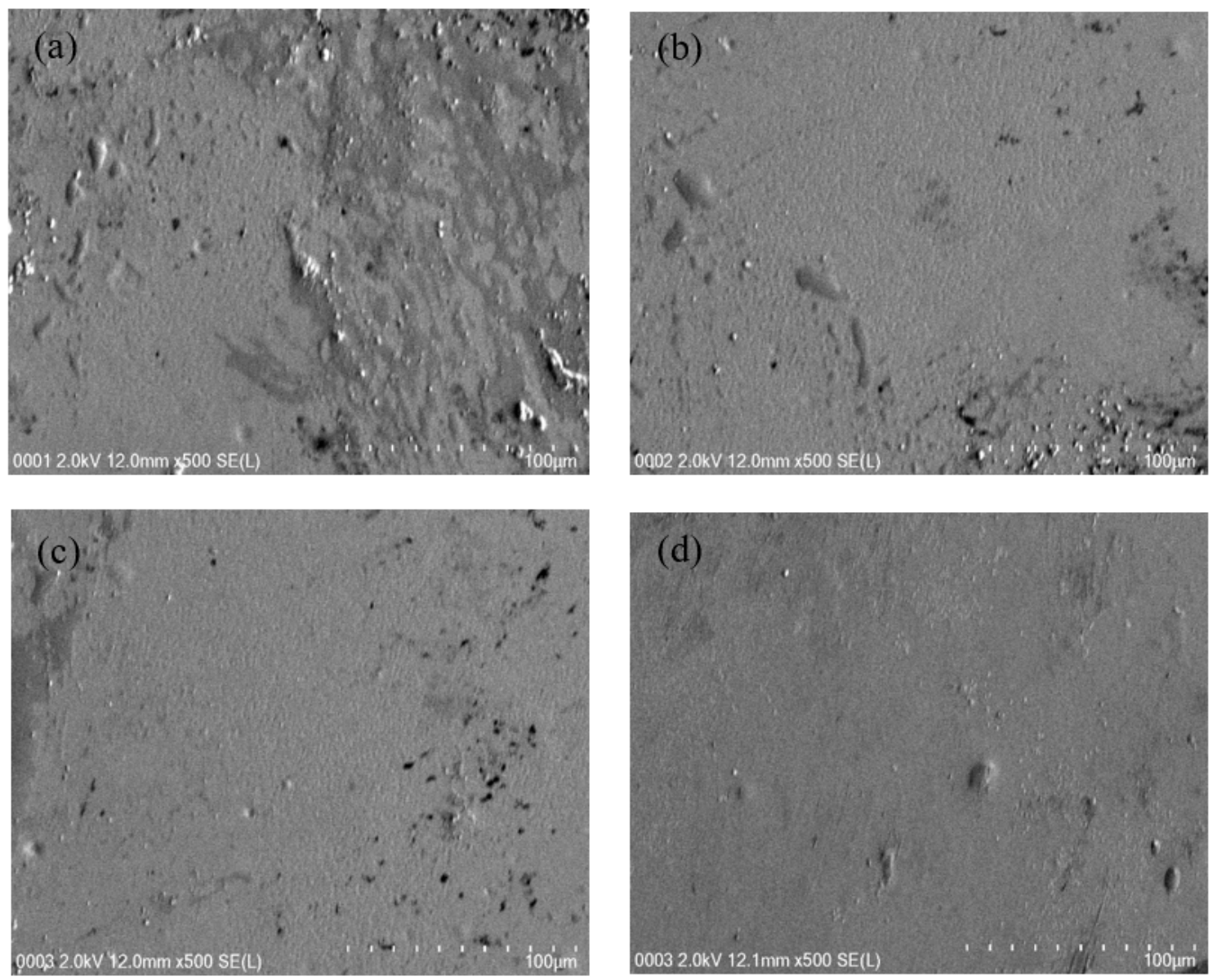

Figure 3. Field emission scanning electron microscopy (FESEM) images (a) CSNZG0, (b) CSNZG1, (c) CSNZG2, and (d) CSNZG3 electrolyte films.
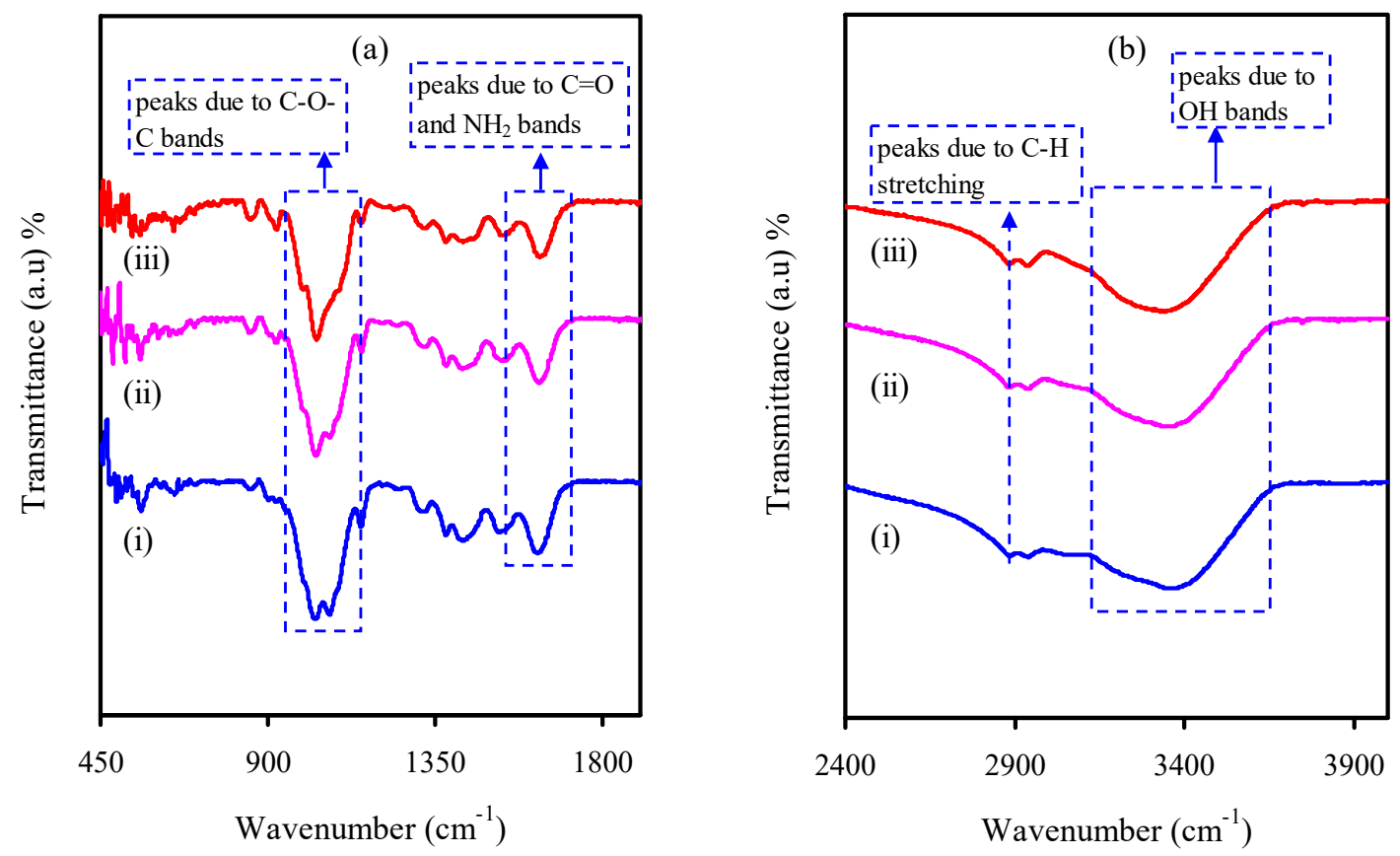

Figure 4. Spectra of (i) CSNZG1, (ii) CSNZG2, and (iii) CSNZG3 electrolyte films in the range (a) 450 to $1900 \mathrm{~cm}^{-1}$ and (b) 2400 to $4000 \mathrm{~cm}^{-1}$. 


\subsection{Dielectric Properties}

\subsubsection{Study of Dielectric Constant and Dielectric Loss}

To investigate the conductivity behavior of polymer electrolytes, the study of dielectric analysis is important [48]. Its measurement plays a vital role in elucidating the molecular relaxation behavior associated with its ionic conductive features upon frequency [49]. Based on the plots of dielectric constant $\left(\varepsilon^{\prime}\right)$ and dielectric loss $\left(\varepsilon^{\prime \prime}\right)$, the dielectric properties of the composite samples were determined using the equations in References [1,2].

Figures 5 and 6 show the frequency dependence of dielectric constant $\left(\varepsilon^{\prime}\right)$, and dielectric loss $\left(\varepsilon^{\prime \prime}\right)$ at room temperature for the CSNZG1, CSNZG2, and CSNZG3 composite electrolyte films, respectively [50-52]. Both figures of dielectric constant and dielectric loss have the same behavior. The plots show the reduction in the dielectric constant and dielectric loss with increasing frequency, while at low-frequency, both dielectric parameters are quite high. This phenomenon indicates the occurrences of space charge effects and electrode polarization at the boundary between the electrodes and electrolyte. Therefore, the periodic reversal of the electric field at high frequency happens more rapidly, which reflects no dispersion of excess ions in the field direction. Consequently, polarization reduces due to charge aggregation, resulting in the observed decrease in dielectric permittivity [53-56]. It is interesting to conclude that further increase of the concentration of glycerol in the system leads to raising the values of $\varepsilon^{\prime}$ and $\varepsilon^{\prime \prime}$ at lower frequency regions. Also, the CSNZG3 composite electrolyte film designates the higher ionic conductor due to its sharp rise in the $\varepsilon^{\prime}$ value $[57,58]$.

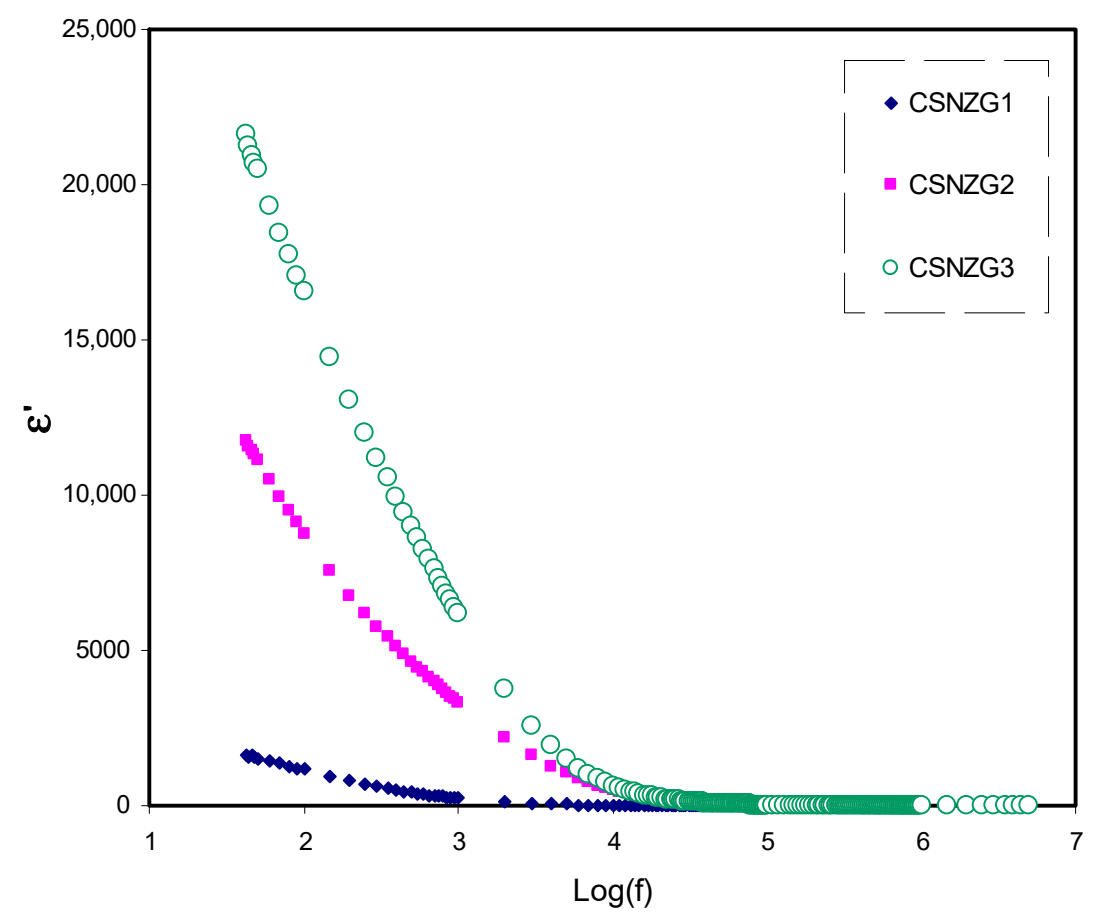

Figure 5. Variation of dielectric constant $\left(\varepsilon^{\prime}\right)$ versus frequency for the CSNZG1, CSNZG2, and CSNZG3 composite electrolyte samples at room temperature. 


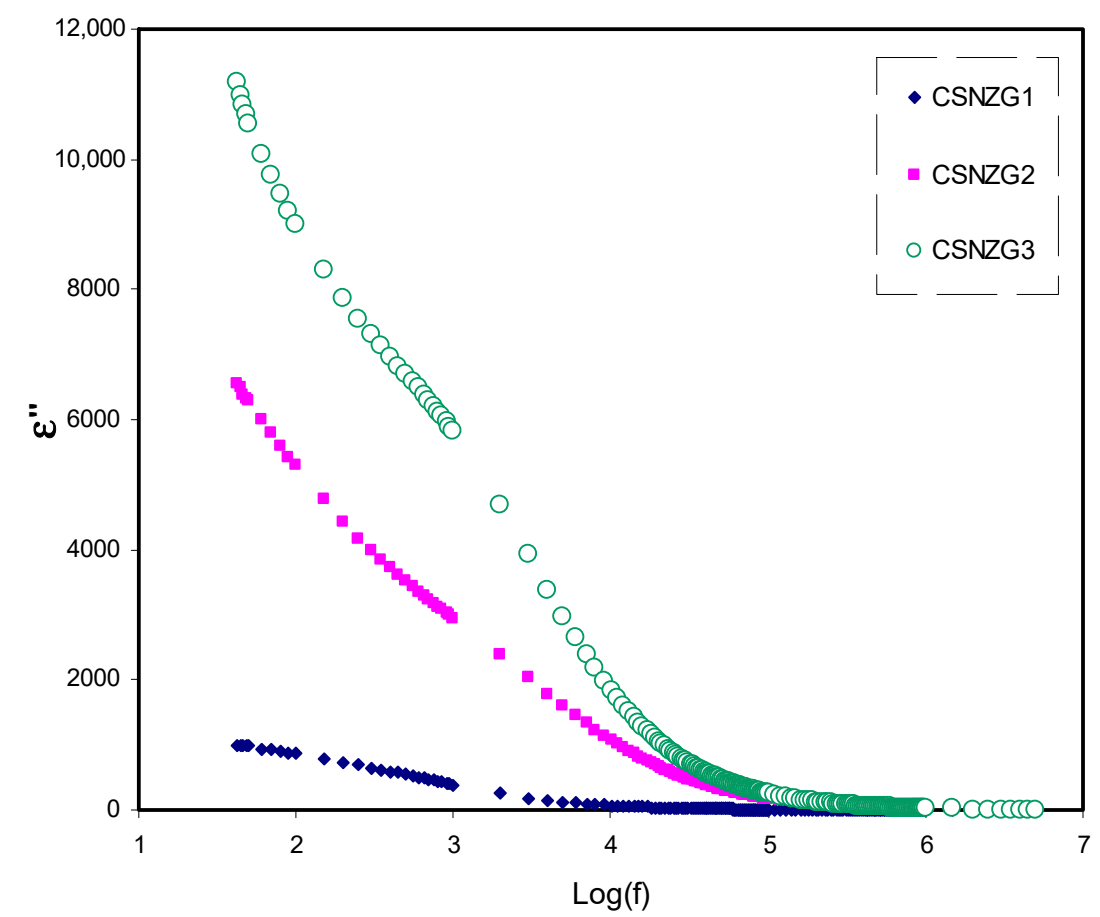

Figure 6. Variation of dielectric loss ( $\left.\varepsilon^{\prime \prime}\right)$ versus frequency for the CSNZG1, CSNZG2, and CSNZG3 composite electrolyte samples at room temperature.

\subsubsection{Electric Modulus Study}

It is of a great opportunity to investigate relaxation processes of polymeric systems using dielectric spectroscopy. The complex dielectric function $\left(\varepsilon^{*}\right)$ comprises dielectric constant and loss, which are very sensitive for the applied frequency and structure of the materials [59-61]. At high frequency, both real $\left(M^{\prime}\right)$ and imaginary $\left(M^{\prime \prime}\right)$ parts of complex modulus are relatively high, owing to the electrode polarization (EP) effect [62,63]. Macedo et al. have established a formalism of electric modulus to minimize the impact of EP [64]. Interestingly, the ion movement in solid polymer electrolytes can perturb the surrounding electric potential. This ion behavior under applied electric potential condition lead to non-exponential decay and distribution of relaxation time [65]. The reciprocal of the permittivity in the complex form is equal to complex electric modulus $\left(\mathrm{M}^{*}\right)[66]$, and can be determined using the equations in References [1,2].

Figures 7 and 8 reveal the frequency dependence of $M^{\prime}$ and $M^{\prime \prime}$ of all the composite electrolyte films. At the low-frequency region, both $M^{\prime}$ and $M^{\prime \prime}$ are small, indicating the absence of electrode polarization contribution in the electric modulus study $[67,68]$. It is interesting to notice that $M^{\prime}$ reaches to a maximum value at the high-frequency region. This is due to decreasing the dielectric constant to a minimum value at the high-frequency region, as shown in Figure 5, and thus $M^{\prime}$ reaches its maximum value $\left(M_{\infty}=1 / \varepsilon_{\infty}\right)$ [69]. Figure 8 shows the frequency dependence of $M^{\prime \prime}$ at different concentrations of plasticizer. At the high-frequency region in the imaginary part of modulus $\left(M^{\prime \prime}\right)$ spectra, a distinct relaxation peak is observed as a result of conductivity processes, while no peak is seen in the dielectric loss spectra, as shown in Figure 6. This confirms the contribution of both ionic and polymer segment motions in the conduction process [70-72]. As a consequence, the conduction process in the polymer electrolytes involves charge transport via ion migration alongside segmental motion. 


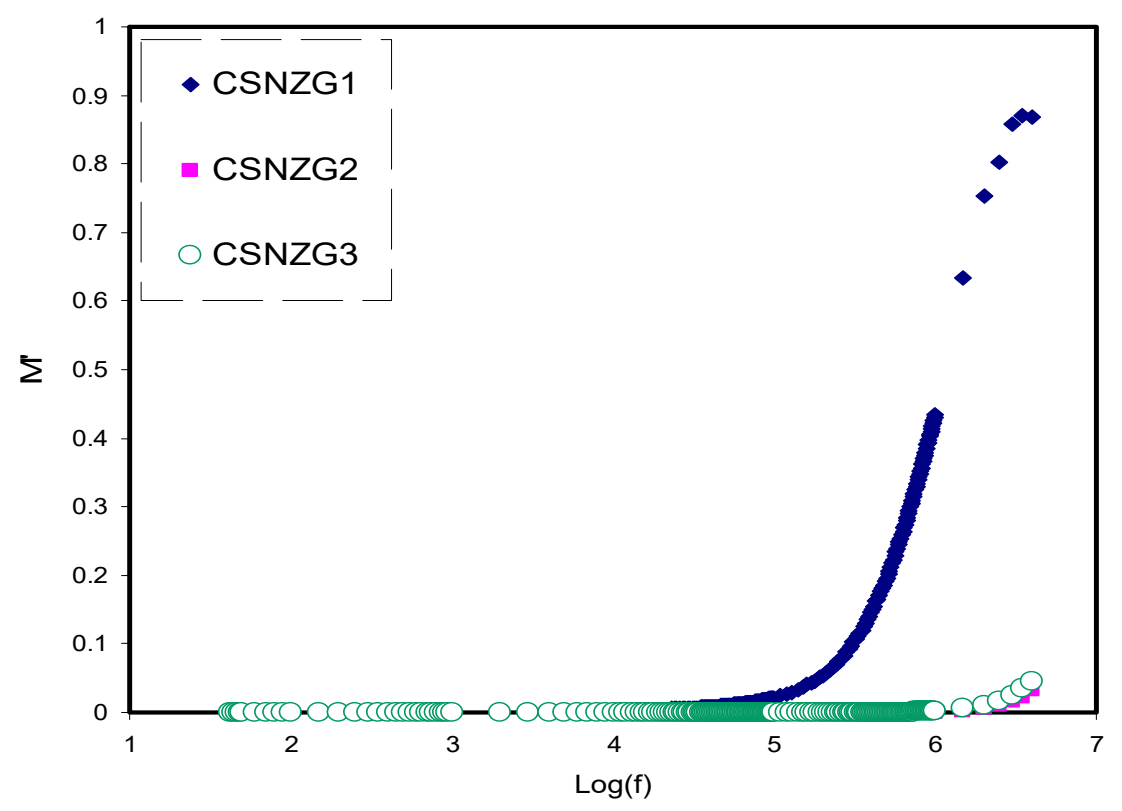

Figure 7. Variation $M^{\prime}$ along with frequency for the CSNZG1, CSNZG2, and CSNZG3 composite electrolyte samples at ambient temperature.

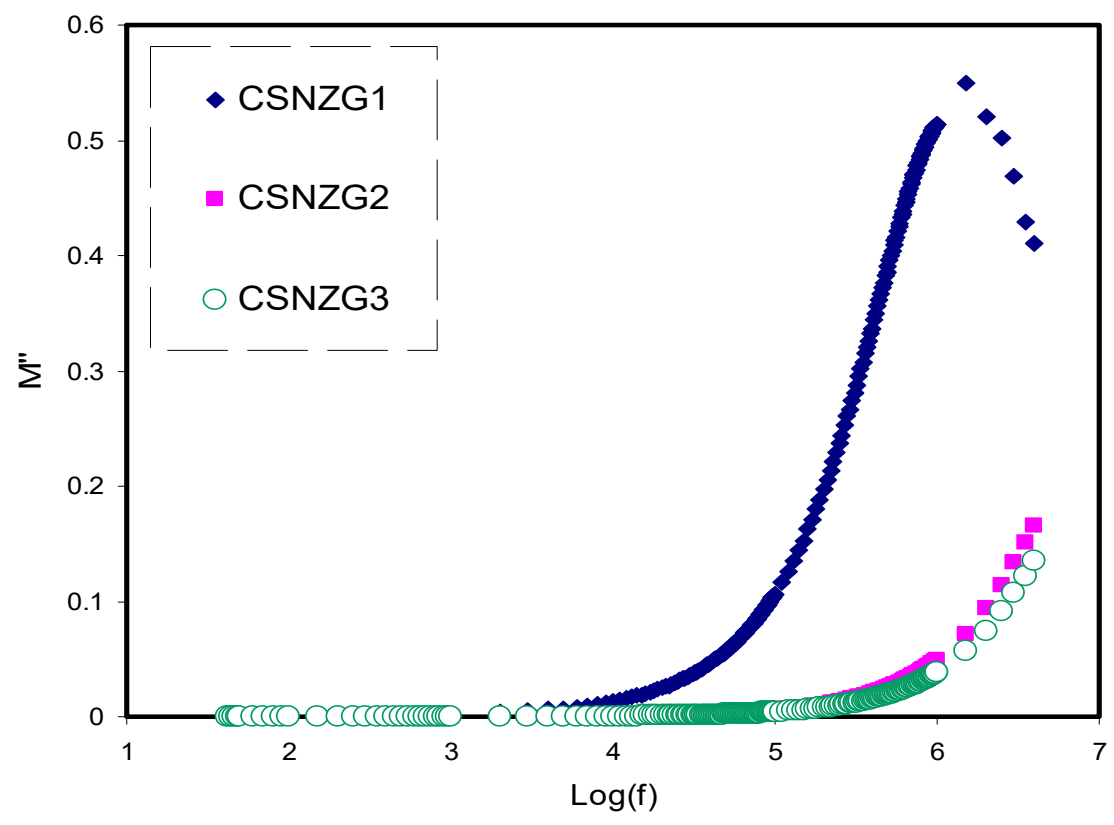

Figure 8. Variation of $M^{\prime \prime}$ along with frequency for the CSNZG1, CSNZG2, and CSNZG3 composite electrolyte samples at ambient temperature.

\subsection{TNM Analysis}

In the composite SPEs, the determination of dominant cation and anion ions can be characterized based on the transference number measurement (TNM). The current was measured through the circuit until it reached a saturation state. The curve of polarization current versus time for the highest conducting system (i.e., CSNZG3) at the working voltage of $0.2 \mathrm{~V}$ is shown in Figure 9. It has been reported that the polymer electrolyte system is governed by cations and anions when the ionic TNM is close to the ideal value of unity [73,74]. In the fabrication of EDLC, it is crucial to confirm which 
species is the main charge carrier to the overall value of conductivity. The following equations are used to calculate the transference number of cations and anions $\left(t_{i o n}\right)$ and electrons $\left(t_{e l}\right)$ :

$$
\begin{aligned}
& t_{i o n}=\frac{I_{i}-I_{s S}}{I_{i}} \\
& t_{e l}=1-t_{i o n}
\end{aligned}
$$

where $t_{i o n}$ is the transference number of cations and anions, $t_{e l}$ is the electron transference number, $I_{i}$ is the initial current holds electrons and cations and anions, and $I_{S S}$ stands for the steady-state current due to electrons only [75,76]. From the graph, an extreme drop in the initial current $(31 \mu \mathrm{A})$ is observed and reduced as a function of time. The large value of current at the beginning is because the electrons, cations, and anions are involved. Cell polarization happens when it reaches the steady state, whereas transfer of the rest of the current is only due to electrons. This is because the stainless-steel electrodes make a barrier for the cations and anions, however they permit the electrons to move through [26]. The current decrement versus time is mainly due to the reduction of cation-carrier and anion-carrier as well as increase the electronic movement in the composite electrolyte system [77]. As a consequence, in the completely depleted charge carriers, the cell becomes constant. Based on the Equations (13) and (14), the measured $t_{i o n}$ and $t_{e l}$ for the sample incorporated with $30 \mathrm{wt} . \%$ glycerol were found to be 0.98 and 0.02 , respectively [78]. The result reveals that the highest conducting sample of the glycerolized CS: $\mathrm{NH}_{4} \mathrm{I}: \mathrm{Zn}$-metal complex system is predominantly due to ions [79]. The TNM finding in this study is similar to the system of chitosan- $\mathrm{NH}_{4} \mathrm{Br}$-glycerol as documented by Shukur et al. [80].

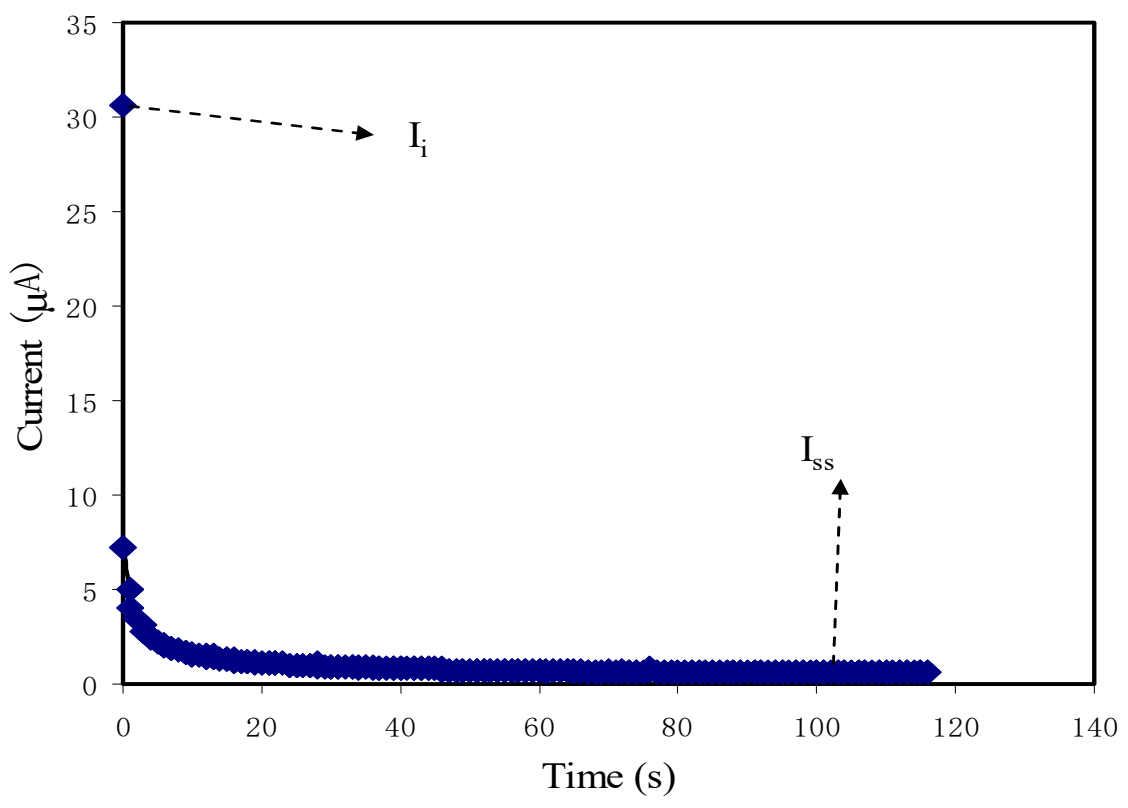

Figure 9. Current versus time for the CSNZG3 electrolyte sample.

\subsection{LSV Analysis}

The use of the linear sweep voltammetry (LSV) technique is to determine the electrochemical stability of the CSNZG3 sample. The EDLC of polymer electrolytes is supposed to be stable and display no peak degradation over the applied potential range [81]. Figure 10 represents the electrochemical stability window of the CSNZG3 electrolyte film at room temperature. A working voltage was measured in the range between 0 and $2.5 \mathrm{~V}$ at the scan rate of $10 \mathrm{mV} / \mathrm{s}$. The LSV plot shows no obvious current in the range from 0 to $1.2 \mathrm{~V}$. As the potential reached $1.3 \mathrm{~V}$, the current was observed to rise steadily. This is indicating the sample decomposition at the surface of the inert electrode [82]. It was reported that the required value of the standard stability window of SPEs in the application of protonic 
devices is $\sim 1 \mathrm{~V}$ [83]. Thus, the prepared CSNZG3 sample possesses adequate anode stability to be applied in electrochemical devices. The breakdown voltage for the starch-chitosan- $\mathrm{NH}_{4} \mathrm{I}$-glycerol system was $1.9 \mathrm{~V}$, as investigated by Yusof et al. [84]. In our previous study, a high breakdown voltage $\left(\mathrm{V}_{\mathrm{b}}\right)$ for the glycerolized CS: $\mathrm{NH}_{4} \mathrm{~F}: \mathrm{Zn}(\mathrm{II})$-complex system was observed [25]. There may be some possible interpretation for the different values of $\mathrm{V}_{\mathrm{b}}$ obtained in the present work compared to our reported one. It could be due to the ionic radius of $\mathrm{F}^{-}$being smaller compared to $\mathrm{I}^{-}$, which makes it possible for better intercalation into the layered cathode structure. Thereby, a weak interaction between $\mathrm{NH}_{4}{ }^{+}$with $\mathrm{I}^{-}$is observed relative to $\mathrm{NH}_{4}{ }^{+}$with $\mathrm{F}^{-}[85,86]$. The lattice energy of $\mathrm{NH}_{4} \mathrm{I}$ is lower than $\mathrm{NH}_{4} \mathrm{~F}$ [87], and thus systems impregnated with $\mathrm{NH}_{4} \mathrm{I}$ may possess lower $\mathrm{V}_{\mathrm{b}}$.

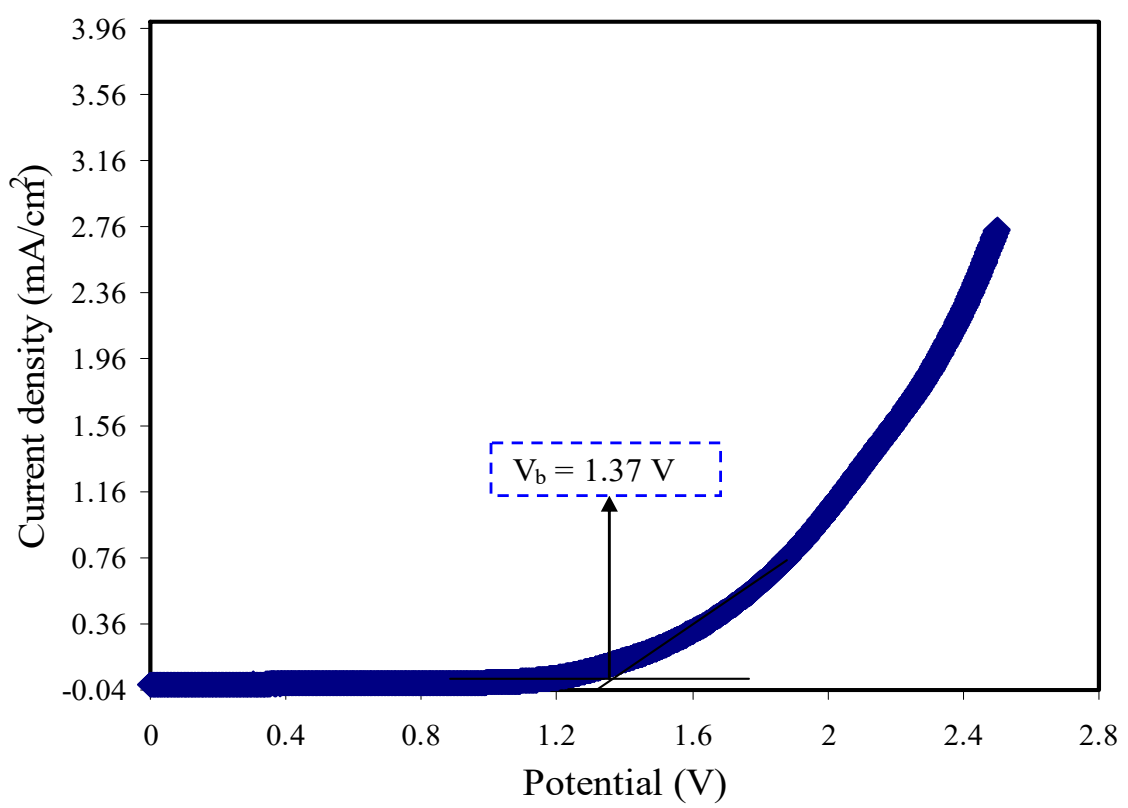

Figure 10. Linear sweep voltammogram (LSV) plot for the highest conducting CSNZG3 electrolyte sample.

\subsection{Cyclic Voltammetry (CV) Analysis}

Over decades, diverse methods in electroanalytical chemistry have been developed. The extreme importance was achieved by cyclic voltammetry (CV) from both the physics and chemistry viewpoints. It is a strong and widespread electrochemical technique to characterize the oxidation-reduction process of molecular materials. Except for rigorously analytical issues, CV has already succeeded classical polarography. Its range of applications was extended from the study of basic redox procedures in organic and inorganic chemistry to the investigation of macromolecular chemistry and biochemistry of the multi-electron transfer process. However, molecular electrochemistry has become a key research technique aimed at improving technologies for clean energy sources $[87,88]$. The electrical capacitor performances and its charge storage will usually be evaluated with cyclic voltammetry $(\mathrm{CV})$ at specific interfaces in the cathodic and anodic regions [89]. Hegde et al. [90] synthesized carbon NSs by a catalyst-free pyrolysis method from bio-waste sago bark. The capacitive behavior of the carbon NSs was proven by the $\mathrm{CV}$ profile at various scan rates which showed nearly rectangular-like shape. The author showed that the fabricated carbon NSs are suitable in SCs electrode application.

Figure 11 shows the $\mathrm{CV}$ responses for the highest conducting sample, where the potential range was measured from 0 to $0.9 \mathrm{~V}$, at various scan rates of $10-100 \mathrm{mV} / \mathrm{s}$. The $\mathrm{CV}$ profile of the constructed EDLC displays a leaf-like shape at the high scan rates, while its shape turned into an almost rectangular shape as the scan rate decreased $[25,91]$. The internal resistance and carbon porosity is the reason for the 
deviation from rectangular shape, thereby producing a current dependence of potential. The specific capacitance $\left(C_{p}\right)$ value from the $\mathrm{CV}$ profile can be determined using the following equation:

$$
C_{p}=\int_{V_{1}}^{V_{2}} \frac{I(V) d V}{2 m S\left(V_{2}-V_{1}\right)}
$$

where $I(V) d V$ is the area of the CV plot, which was determined using the Origin 9.0 software via the function of integration. $V_{1}$ and $V_{2}$ are the initial voltage and final voltage, respectively. $m$ stands for the mass of active material used, and $S$ is the scan rate [92]. It is interesting to note that the $C V$ plots possess no visible redox reaction peaks over its entire potential range. It is also obvious that the variation of scan rates influenced the shape of the CV plots and $C_{p}$ values (see Table 5). At higher scan rates, the amount of accumulated charges on the surface of the electrodes is decreased, due to the contribution of little charges for polarization, thus, the $C_{p}$ value is reduced [93-95]. At a lower scan rate, the rectangular-like shape of the fabricated EDLC is an indication for the fact that the characteristics of the EDLC are near to an ideal capacitor behavior. Arof et al. [96] achieved the $C_{p}$ value of $35 \mathrm{~F} / \mathrm{g}$ for the polymer electrolyte system of CS/iota-carrageenan-based EDLC. The $C_{p}$ value of $32.69 \mathrm{~F} / \mathrm{g}$ was obtained for the system of glycerolized PVA:CS: $\mathrm{Mg}\left(\mathrm{CF}_{3} \mathrm{SO}_{3}\right)_{2}$ at $10 \mathrm{mV} / \mathrm{s}$ [97].

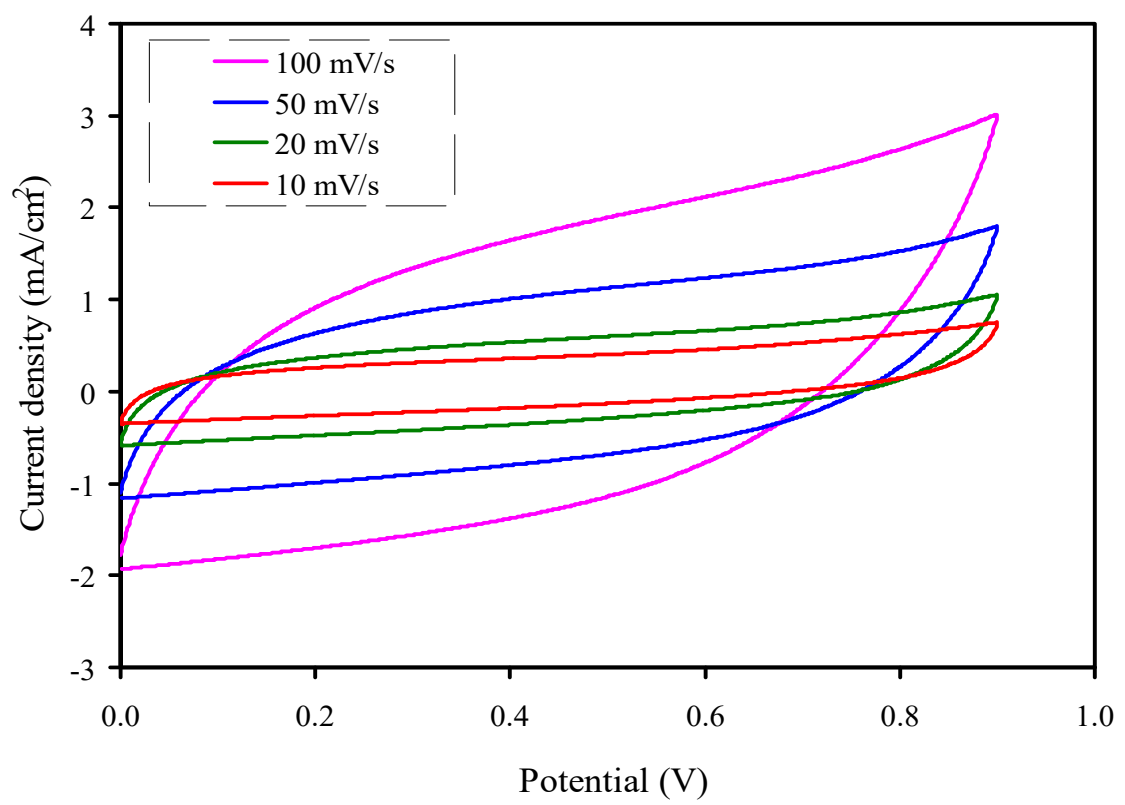

Figure 11. CV curve of the EDLC measured for the CSNZG3 sample at different sweep rates in the potential range of 0 to $0.9 \mathrm{~V}$.

Table 5. Specific capacitance $\left(C_{p}\right)$ value of the CSNZG3 film at the various scan rates of $100,50,20$, and $10 \mathrm{mV} / \mathrm{s}$.

\begin{tabular}{ccccc}
\hline Scan Rate $(\mathbf{m V} / \mathbf{s})$ & Area & Mass $(\mathrm{g})$ & $\mathbf{V}_{\mathbf{2}}-\mathbf{V}_{\mathbf{1}}$ & Specific Capacitance $(\mathrm{F} / \mathbf{g})$ \\
\hline 100 & $6.70 \times 10^{-3}$ & $2.43 \times 10^{-3}$ & 0.9 & 15.32 \\
50 & $4.22 \times 10^{-3}$ & $2.43 \times 10^{-3}$ & 0.9 & 19.29 \\
20 & $2.20 \times 10^{-3}$ & $2.43 \times 10^{-3}$ & 0.9 & 25.14 \\
10 & $1.38 \times 10^{-3}$ & $2.43 \times 10^{-3}$ & 0.9 & 31.55 \\
\hline
\end{tabular}

\subsection{Analysis of Charge-Discharge Characteristic}

A galvanostatic charge-discharge (GCD) profile of the fabricated EDLC device for the maximum conducting composite electrolyte containing $30 \mathrm{wt} . \%$ of glycerol is illustrated in Figure 12. The applied current density is $0.5 \mathrm{~mA} / \mathrm{cm}^{2}$ over 400 cycles in the potential range between 0 and $0.9 \mathrm{~V}$ at room 
temperature [98]. The EDLC charge and discharge curve displays as almost linear, which indicates the capacitive behavior of the EDLC [99].

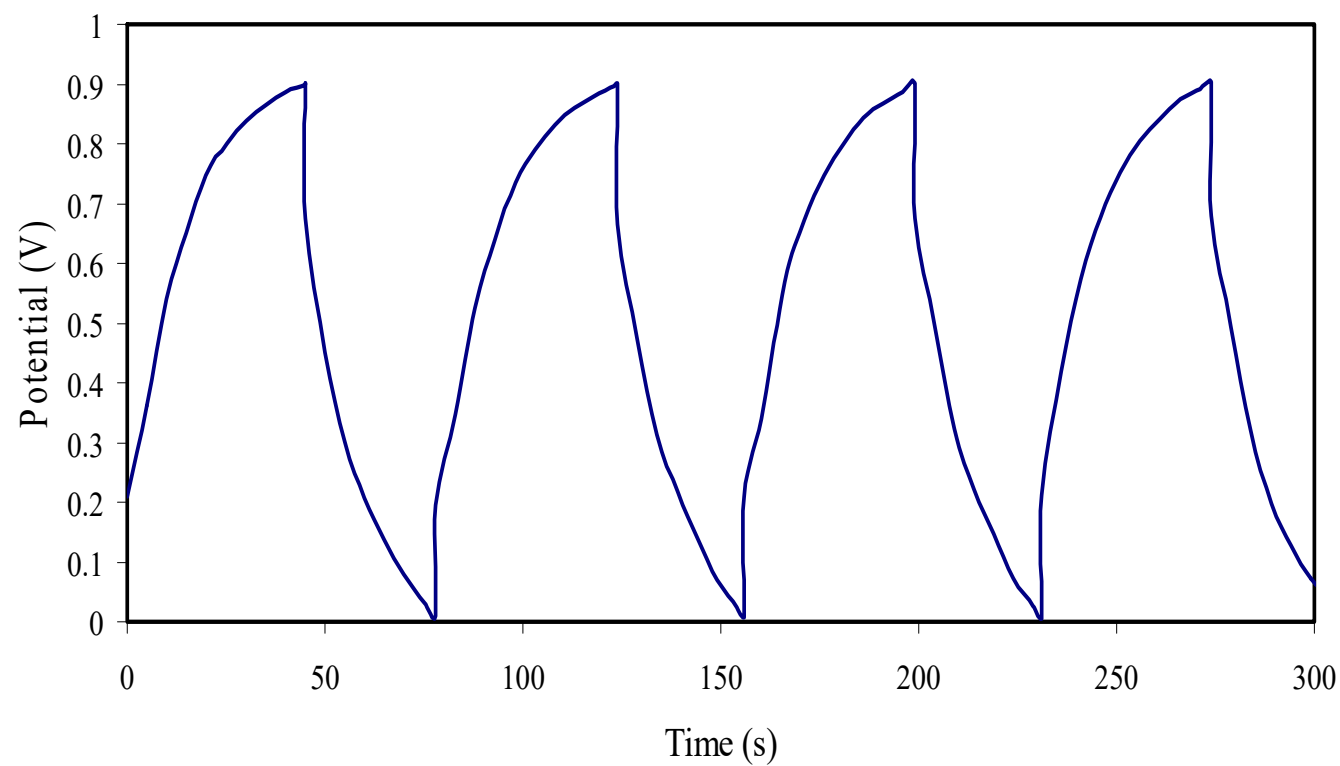

Figure 12. Galvanostatic charge-discharge performances of the constructed EDLC for the initial cycles.

One may notice the rapid drop in the potential $\left(\mathrm{V}_{\mathrm{d}}\right)$ of the assembled EDLC before the initiation of the discharging process. It is obvious that a perfect triangle shape of the charge-discharge curve cannot be obtained. The deviation from the ideal triangle shape may be related to the influence of internal resistance, bulk electrolyte, and roughness of activated carbon $[100,101]$.

The capacitance is the ratio between the changes of electrical charge to the change of the potential within a system. Figure 13 a represents the variation of the discharge-specific capacitance $\left(C_{S}\right)$ of the constructed EDLC up to 400 cycles. The value of the $C_{S}$ of the EDLC was calculated from the following equation:

$$
C_{s}=\frac{i}{g m}
$$

where $i$ is the applied potential, $g$ is the discharge part gradient, and $m$ is the active material mass. Obviously, the $C_{S}$ value at the first cycle was found to be $36 \mathrm{~F} / \mathrm{g}$ and followed by a dropped to $19.5 \mathrm{~F} / \mathrm{g}$ as the cycle number increased to the 50th cycle. The decrease in the $C_{s}$ value could be due to not having very good contact between the electrolyte and electrodes [102-104]. In this work, the average value of specific capacitance $\left(C_{S}\right)$ was found to be $\sim 19 \mathrm{~F} / \mathrm{g}$. The obtained $C_{s}$ value in this study is of great interest in comparison with those measured for other proton-based EDLC works. Our previous studies for CS:MC: $\mathrm{NH}_{4} \mathrm{I}$ [105], CS:Dextran: $\mathrm{NH}_{4} \mathrm{~F}$ [106], and methylcellulose (MC):CS (CS): $\mathrm{NH}_{4} \mathrm{I}$ :glycerol systems displayed $C_{S}$ values of $1.76,12$, and $10 \mathrm{~F} / \mathrm{g}$, respectively [21]. Shuhaimi et al. [15] reported the $C_{S}$ value of $1.67 \mathrm{~F} / \mathrm{g}$ for the system of $\mathrm{MC}-\mathrm{NH}_{4} \mathrm{NO}_{3}$. It is obvious from Figure 13 that the Cs drops continuously with increasing the number of cycles. Anion ions from the $\mathrm{NH}_{4} \mathrm{I}$ salt possess a bigger radius, and it may begin blocking some of those ions in the electrode pores throughout its charge-discharge process. In its next charge-discharge step, these blocked ions will create a repulsive force to the same ions. Consequently, with the number of cycles, it could reduce the cyclic stability of the system [107]. 

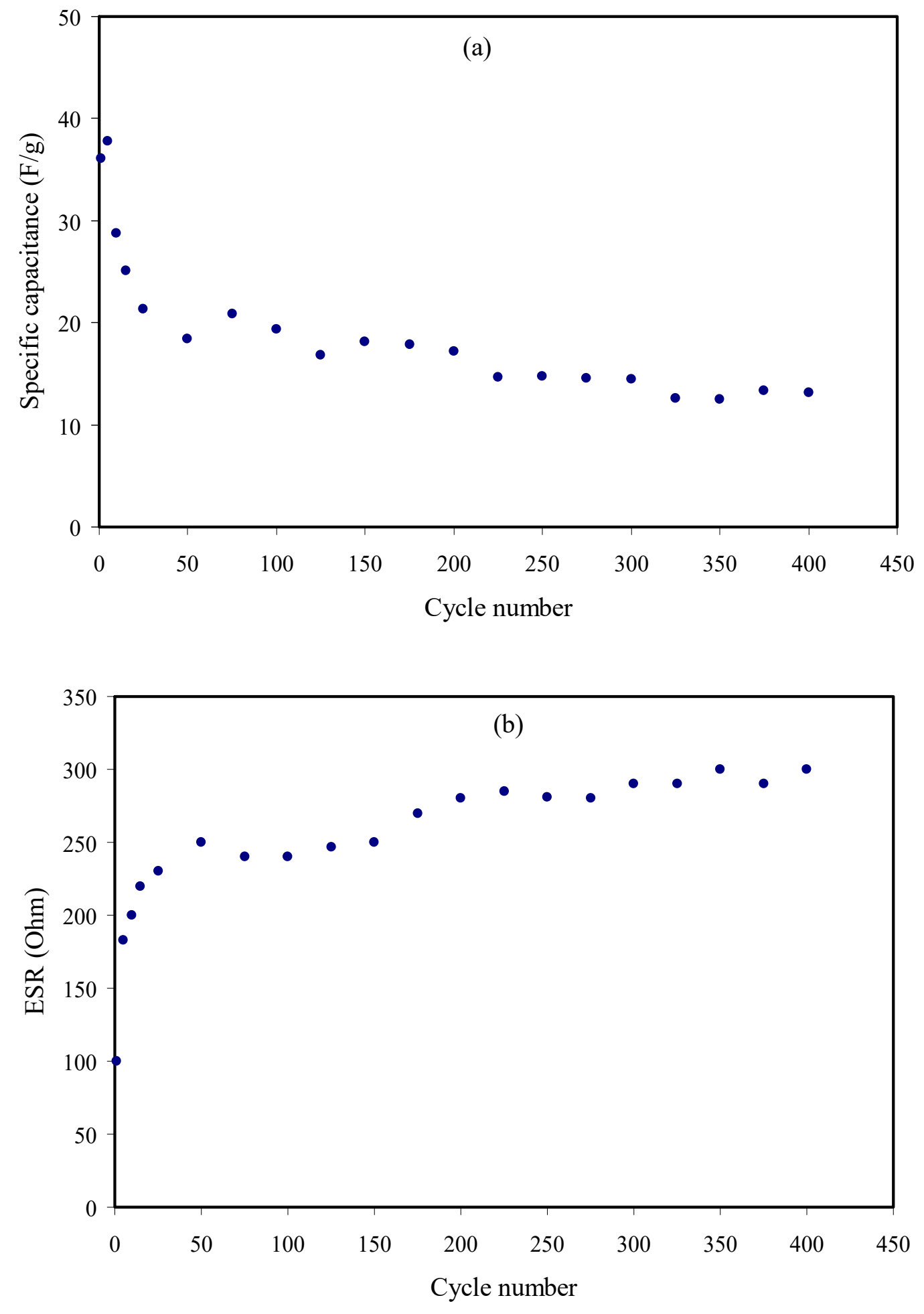

Figure 13. Cont. 

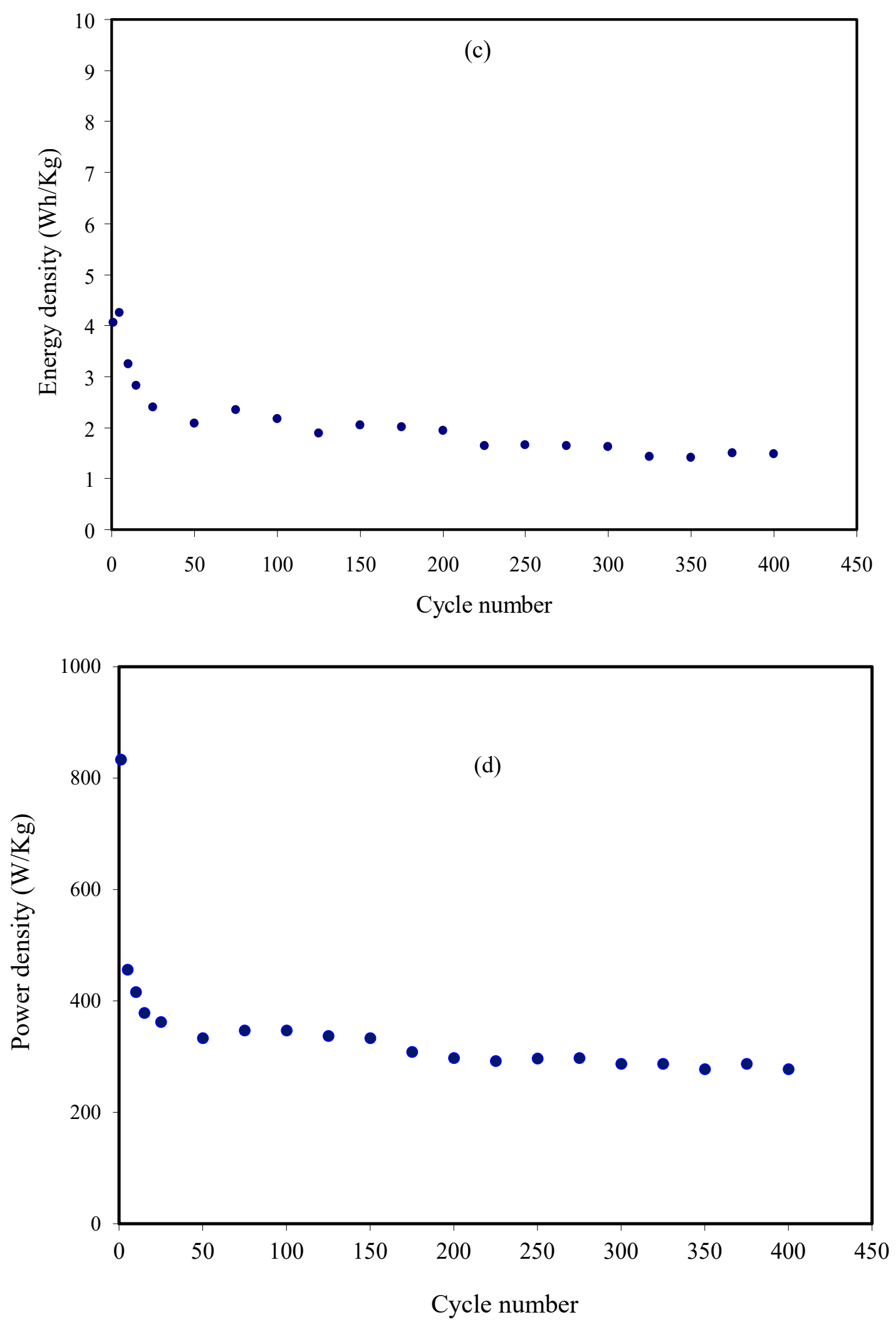

Figure 13. EDLC parameters of (a) specific capacitance $\left(C_{S}\right),(\mathbf{b})$ equivalence series resistance $(E S R)$, (c) energy density $\left(E_{d}\right)$, and $(\mathbf{d})$ power density $\left(P_{d}\right)$ versus cycle number. 
The variation of the equivalence series resistance (ESR) of the fabricated EDLC versus cycle number is shown in Figure 13b. The ESR value of the EDLC was obtained via the equation below:

$$
E S R=\frac{V_{d}}{i}
$$

where $V_{d}$ denotes the drop potential before the start of the discharging process, and $i$ stands for the applied current. It is noteworthy that the value of the ESR acquired at the first cycle was found to be $177 \Omega$. It is also noticeable that the ESR value increases with the increment of cycle number, and attained the highest value of $300 \Omega$ at the 350th cycle number, resulting from the maximum value of $V_{d}$. The presence of internal resistance $\left(R_{e s}\right)$ in the EDLC, which is also known as equivalence series resistance (ESR), can be related to the current collector, the charge-discharge procedure of electrolytes, and the distance between the polymer electrolyte and electrodes $[3,108]$. A low ESR value is promising for the applications of the EDLC. Besides, it can verify a strong interaction between electrolytes and electrodes through a low ESR value. The same trend in the ESR was recorded for the system of CS:MC: $\mathrm{NH}_{4} \mathrm{I}$ [105]. The system of CS:Starch: $\mathrm{NH}_{4} \mathrm{I}$ showed a very high ESR value compared to the current work [109]. Our previous study for the glycerolized PVA: $\mathrm{NH}_{4} \mathrm{SCN}: \mathrm{Cd}(\mathrm{II})$-complex showed the average ESR value of $51 \Omega$ [2].

The energy density $\left(E_{d}\right)$ and power density $\left(P_{d}\right)$ are two crucial parameters that should be characterized to approve the application of the EDLC device. Figure $13 \mathrm{c}, \mathrm{d}$ provide the $E_{d}$ and $P_{d}$ densities throughout 400 cycles for the highest conducting sample of the glycerolized CS: $\mathrm{NH}_{4} \mathrm{I}: \mathrm{Zn}$ (II)-complex system. The $E_{d}$ and $P_{d}$ have been calculated using the equations in References $[110,111]$.

The $E_{d}$ value in the first cycle was found to be $4.1 \mathrm{Wh} / \mathrm{kg}$, while it dropped to $2.1 \mathrm{Wh} / \mathrm{kg}$ at the 50th cycle. Beyond the 50th cycle, the $E_{d}$ values are almost constant until 400th cycle, with an average of $\sim 2 \mathrm{Wh} / \mathrm{kg}$ (see Figure 13c). At this point, ions subject the same energy barrier as it transports from the polymer electrolyte to the surface of the electrodes [112-114]. The ion accumulation at the electrode/electrolyte interfaces has a significant effect on the amount of energy storage in EDLC. Hamsan et al. [110] have stated an $E_{d}$ value of $2.25 \mathrm{Wh} / \mathrm{kg}$ using the potato starch (PS)-methylcellulose(MC)- $\mathrm{NH}_{4} \mathrm{NO}_{3}$-glycerol system. Our previous work for the CS:MC: $\mathrm{NH}_{4} \mathrm{I}:$ glycerol system showed an $E_{d}$ value of $0.77 \mathrm{Wh} / \mathrm{kg}$, which is much lower than that reported in this study [21]. From Figure 13d, it was observed that the $P_{d}$ value at the first cycle is about $480 \mathrm{~W} / \mathrm{kg}$, while it decreased to $320 \mathrm{~W} / \mathrm{kg}$ when it reached the 50th cycle as a result of an increase in the ESR and $V_{d}$. Afterward, it was stable up to the 400th cycle, with an average value of $\sim 300 \mathrm{~W} / \mathrm{kg}$. The $P_{d}$ value at the first cycle for the system of PVA-CS-NH $\mathrm{N}_{4} \mathrm{SCN}$-glycerol [16] was $399 \mathrm{~W} / \mathrm{kg}$, which is comparable with the result in this study.

\section{Conclusions}

The glycerolized CS: $\mathrm{NH}_{4} \mathrm{I}: \mathrm{Zn}(\mathrm{II})$-complex-based polymer composite electrolytes (PCEs) were prepared via the technique of cast solution. Polymer electrolytes are scientifically imperative in the fabrication of electrochemical SCs, fuel cells, batteries, and dye-sensitized solar cells. The ionic conductivity and dielectric properties were observed to be improved with increasing glycerol concentration. The sample incorporated with $30 \mathrm{wt} . \%$ of glycerol exhibited the highest dielectric constant with the maximum ionic conductivity of $1.17 \times 10^{-4} \mathrm{~S} / \mathrm{cm}$. It was shown that when the glycerol amount increased, the diffusion coefficient $(D)$, mobility $(\mu)$, and number density $(n)$ of cations and anions fractions gradually increased. The $\mathrm{Zn}(\mathrm{II})$-complex improved the EDLC performance because of the enhancement of the amorphous nature, whereas the high ionic conductivity is associated to the amorphous structure. It was indicated by the FESEM method that at the highest glycerol amount, the film has a smooth and homogenous surface morphology. It was indicated by the FTIR spectroscopy that there was an interaction of $\mathrm{NH}_{4} \mathrm{I}, \mathrm{Zn}(\mathrm{II})$-complex, and glycerol with the CS polymer by modifying the FTIR bands. Transference number measurements (TNM) confirmed that the dominant charge carriers were cations and anions fractions. The value of the cation and anion transference number 
$\left(t_{i o n}\right)$ fraction was found to be 0.98 . The electron transference number $\left(t_{e}\right)$ for the highest conducting electrolyte was identified to be 0.02 . The measures of the LSV displayed that the CSNZG3 sample was decomposed at $1.37 \mathrm{~V}$, suggesting the electrolyte suitability for the EDLC application. The CV curves showed no redox reaction peaks throughout its entire potential range. To evaluate the characteristics of the EDLCs composed of the glycerolized CS-based PCEs, cyclic voltammetry (CV) and the galvanostatic charge-discharge (GCD) curve were applied over 400 cycles. The fabricated EDLC showed that the initial value of specific capacitance $\left(C_{s}\right)$, equivalence series resistance (ESR), energy density $\left(E_{d}\right)$, and power density $\left(P_{d}\right)$ were found to be $36 \mathrm{~F} / \mathrm{g}, 177 \Omega, 4.1 \mathrm{Wh} / \mathrm{kg}$, and $480 \mathrm{~W} / \mathrm{kg}$, respectively.

Author Contributions: Conceptualization, S.B.A., M.F.Z.K. and S.K.M.; Formal analysis, M.A.B. and M.H.H.; Investigation, M.H.H.; Project administration, S.B.A., S.R.S. and M.F.Z.K.; Supervision, S.B.A.; Validation, J.M.H., S.B.A., S.R.S., M.A.B., R.T.A., R.M.A., M.F.Z.K. and S.K.M.; Writing-original draft, J.M.H.; Writing一review and editing, S.B.A., S.R.S., M.A.B., R.T.A., R.M.A., M.F.Z.K. and S.K.M. All authors have read and agreed to the published version of the manuscript.

Funding: This research received no external funding.

Acknowledgments: The authors acknowledge the support for this project from the University of Sulaimani, Charmo University, University of Malaya, and Komar University of Science and Technology.

Conflicts of Interest: The authors declare no conflict of interest.

\section{References}

1. Brza, M.A.; Aziz, S.B.; Anuar, H.; Ali, F.; Hamsan, M.H.; Kadir, M.F.Z. Metal Framework as a Novel Approach for the Fabrication of Electric Double Layer Capacitor Device with High Energy Density Using Plasticized Poly(vinyl alcohol): Ammonium Thiocyanate Based Polymer Electrolyte. Arab. J. Chem. 2020. [CrossRef]

2. Brza, M.A.; Aziz, S.B.; Anuar, H.; Dannoun, E.M.A.; Ali, F.; Abdulwahid, R.T.; Al-Zangana, S.; Kadir, M.F.Z. The Study of EDLC Device with High Electrochemical Performance Fabricated from Proton Ion Conducting PVA-Based Polymer Composite Electrolytes Plasticized with Glycerol. Polymers 2020, 12, 1896. [CrossRef] [PubMed]

3. Sownthari, K.; Suthanthiraraj, S.A. Synthesis and characterization of an electrolyte system based on a biodegradable polymer. Express Polym. Lett. 2013, 7, 495-504. [CrossRef]

4. Hadi, J.M.; Aziz, S.B.; Mustafa, M.S.; Brza, M.A.; Hamsan, M.H.; Kadir, M.F.Z.; Ghareeb, H.O.; Hussein, S.A. Electrochemical impedance study of proton conducting polymer electrolytes based on PVC doped with thiocyanate and plasticized with glycerol. Int. J. Electrochem. Sci. 2020, 15, 4671-4683. [CrossRef]

5. Aziz, S.B.; Woo, T.J.; Kadir, M.F.Z.; Ahmed, H.M. A conceptual review on polymer electrolytes and ion transport models. J. Sci. Adv. Mater. Devices 2018, 3, 1-17. [CrossRef]

6. Sudhakar, Y.N.; Selvakumar, M. Lithium perchlorate doped plasticized chitosan and starch blend as biodegradable polymer electrolyte for supercapacitors. Electrochim. Acta 2012, 78, 398-405. [CrossRef]

7. Zulkifli, A.M.; Said, N.I.; Bakr Aziz, S.; Dannoun, E.M.; Hisham, S.; Shah, S.; Abu Bakar, A.; Zainal, Z.H.; Tajuddin, H.A.; Mohammed Hadi, J.; et al. Characteristics of Dye-Sensitized Solar Cell Assembled from Modified Chitosan-Based Gel Polymer Electrolytes Incorporated with Potassium Iodide. Molecules 2020, 25, 4115. [CrossRef] [PubMed]

8. Ngai, K.S.; Ramesh, S.; Ramesh, K.; Juan, J.C. A review of polymer electrolytes: Fundamental, approaches and applications. Ionics 2016, 22, 1259-1279. [CrossRef]

9. Aziz, S.B.; Brza, M.A.; Saed, S.R.; Hamsan, M.H.; Kadir, M.F.Z. Ion association as a main shortcoming in polymer blend electrolytes based on CS:PS incorporated with various amounts of ammonium tetrafluoroborate. J. Mater. Res. Technol. 2020, 9, 5410-5421. [CrossRef]

10. Itoh, T. Hyperbranched polymer electrolytes for high temperature fuel cells. Polym. Electrolytes 2010, 524-549. [CrossRef]

11. Libich, J.; Máca, J.; Vondrák, J.; Čech, O.; Sedlaříková, M. Supercapacitors: Properties and applications. J. Energy Storage 2018, 17, 224-227. [CrossRef]

12. Zhang, S. Eliminating pre-lithiation step for making high energy density hybrid Li-ion capacitor. J. Power Sources 2017, 343, 322-328. [CrossRef] 
13. Zhang, D.; Zhang, X.; Chen, Y.; Yu, P.; Wang, C.; Ma, Y. Enhanced capacitance and rate capability of graphene/polypyrrole composite as electrode material for supercapacitors. J. Power Sources 2011, 196, 5990-5996. [CrossRef]

14. Ji, Y.; Liang, N.; Xu, J.; Qu, R.; Chen, D.; Zhang, H. Solid polymer electrolyte membranes based on quaternized polysulfone and solvent-free fluid as separators for electrical double-layer capacitors. Electrochim. Acta 2018, 283, 97-103. [CrossRef]

15. Shuhaimi, N.E.A.; Teo, L.P.; Woo, H.J.; Majid, S.R.; Arof, A.K. Electrical double-layer capacitors with plasticized polymer electrolyte based on methyl cellulose. Polym. Bull. 2012, 69, 807-826. [CrossRef]

16. Aziz, S.B.; Hadi, J.M.; Elham, E.M.; Abdulwahid, R.T.; Saeed, S.R.; Marf, A.S.; Karim, W.O.; Kadir, M.F.Z. The study of plasticized amorphous biopolymer blend electrolytes based on polyvinyl alcohol (PVA): Chitosan with high ion conductivity for energy storage electrical double-layer capacitors (EDLC) device application. Polymers 2020, 12, 1938. [CrossRef] [PubMed]

17. Francis, K.A.; Liew, C.W.; Ramesh, S.; Ramesh, K.; Ramesh, S. Ionic liquid enhanced magnesium-based polymer electrolytes for electrical double-layer capacitors. Ionics 2016, 22, 919-925. [CrossRef]

18. Ali, G.A.M.; Divyashree, A.; Supriya, S.; Chong, K.F.; Ethiraj, A.S.; Reddy, M.V.; Algarni, H.; Hegde, G. Carbon nanospheres derived from Lablab purpureus for high performance supercapacitor electrodes: A green approach. Dalton Trans. 2017, 46, 14034. [CrossRef]

19. Yadav, N.; Mishra, K.; Hashmi, S.A. Optimization of porous polymer electrolyte for quasi-solid-state electrical double layer supercapacitor. Electrochim. Acta 2017, 235, 570-582. [CrossRef]

20. Shukur, M.F.; Ithnin, R.; Illias, H.A.; Kadir, M.F.Z. Proton conducting polymer electrolyte based on plasticized chitosan-PEO blend and application in electrochemical devices. Opt. Mater. 2013, 35, 1834-1841. [CrossRef]

21. Aziz, S.B.; Hamsan, M.H.; Brza, M.A.; Kadir, M.F.Z.; Muzakir, S.K.; Abdulwahid, R.T. Effect of glycerol on EDLC characteristics of chitosan:methylcellulose polymer blend electrolytes. J. Mater. Res. Technol. 2020, 9 , 8355-8366. [CrossRef]

22. Nishihara, H.; Itoi, H.; Kogure, T.; Hou, P.X.; Touhara, H.; Okino, F.; Kyotani, T. Investigation of the ion storage/transfer behavior in an electrical double- layer capacitor by using ordered microporous carbons as model materials. Chem. A Eur. J. 2009, 15, 5355-5363. [CrossRef] [PubMed]

23. Balathanigaimani, M.S.; Shim, W.G.; Lee, M.J.; Kim, C.; Lee, J.W.; Moon, H. Highly porous electrodes from novel corn grains-based activated carbons for electrical double layer capacitors. Electrochem. Commun. 2008, 10, 868-871. [CrossRef]

24. Kumar, Y.; Pandey, G.P.; Hashmi, S.A. Gel polymer electrolyte based electrical double layer capacitors: Comparative study with multiwalled carbon nanotubes and activated carbon electrodes. J. Phys. Chem. C 2012, 116, 26118-26127. [CrossRef]

25. Asnawi, A.S.F.M.; Aziz, S.B.; Nofal, M.M.; Yusof, Y.M.; Brevik, I.; Hamsan, M.H.; Brza, M.A.; Abdulwahid, R.T.; Kadir, M.F.Z. Metal Complex as a Novel Approach to Enhance the Amorphous Phase and Improve the EDLC Performance of Plasticized Proton Conducting Chitosan-Based Polymer Electrolyte. Membranes 2020, 10, 132. [CrossRef]

26. Brza, M.A.; Aziz, S.B.; Anuar, H.; Ali, F. Structural, ion transport parameter and electrochemical properties of plasticized polymer composite electrolyte based on PVA: A novel approach to fabricate high performance EDLC devices. Polym. Test. 2020, 91, 106813. [CrossRef]

27. Brza, M.A.; Aziz, S.B.; Anuar, H.; Ali, F.; Dannoun, E.M.; Mohammed, S.J.; Abdulwahid, R.T.; Al-Zangana, S. Tea from the drinking to the synthesis of metal complexes and fabrication of PVA based polymer composites with controlled optical band gap. Sci. Rep. 2020, 10, 18108. [CrossRef]

28. Bourtoom, T. Plasticizer effect on the properties of biodegradable blend from rice starch-chitosan. Songklanakarin J. Sci. Technol. 2008, 30 (Suppl. 1), 149-155.

29. Brza, M.A.; Aziz, S.B.; Anuar, H.; Al Hazza, M.H.F. From green remediation to polymer hybrid fabrication with improved optical band gaps. Int. J. Mol. Sci. 2019, 20, 3910. [CrossRef]

30. Lai, W.; Haile, S.M. Impedance spectroscopy as a tool for chemical and electrochemical analysis of mixed conductors: A case study of ceria. J. Am. Ceram. Soc. 2005, 88, 2979-2997. [CrossRef]

31. Randviir, E.P.; Banks, C.E. Electrochemical Impedance Spectroscopy-An Overview|ScienceDirect Topics. Available online: https://www.sciencedirect.com/topics/chemistry/electrochemical-impedance-spectroscopy (accessed on 18 October 2020). 
32. Samsudin, A.S.; Isa, M.I.N. Characterization of carboxy methylcellulose doped with DTAB as new types of biopolymer electrolytes. Bull. Mater. Sci. 2012, 35, 1123-1131. [CrossRef]

33. Aziz, S.B.; Abdullah, R.M.; Rasheed, M.A.; Ahmed, H.M. Role of ion dissociation on DC conductivity and silver nanoparticle formation in PVA:AgNt based polymer electrolytes: Deep insights to ion transport mechanism. Polymers 2017, 9, 338. [CrossRef] [PubMed]

34. Malathi, J.; Kumaravadivel, M.; Brahmanandhan, G.M.; Hema, M.; Baskaran, R.; Selvasekarapandian, S. Structural, thermal and electrical properties of $\mathrm{PVA}-\mathrm{LiCF}_{3} \mathrm{SO}_{3}$ polymer electrolyte. J. Non Cryst. Solids 2010, 356, 2277-2281. [CrossRef]

35. Aziz, S.B.; Karim, W.O.; Ghareeb, H.O. The deficiency of chitosan: $\mathrm{AgNO}_{3}$ polymer electrolyte incorporated with titanium dioxide filler for device fabrication and membrane separation technology. J. Mater. Res. Technol. 2020. [CrossRef]

36. Aziz, S.B.; Abdullah, O.G.; Saeed, S.R.; Ahmed, H.M. Electrical and dielectric properties of copper ion conducting solid polymer electrolytes based on chitosan: CBH model for ion transport mechanism. Int. J. Electrochem. Sci. 2018, 13, 3812-3826. [CrossRef]

37. Asnawi, A.S.F.M.; Aziz, S.B.; Nofal, M.M.; Hamsan, M.H.; Brza, M.A.; Yusof, Y.M.; Abdilwahid, R.T.; Muzakir, S.K.; Kadir, M.F.Z. Glycerolized Li+ ion conducting chitosan-based polymer electrolyte for energy storage EDLC device applications with relatively high energy density. Polymers 2020, 12, 1433. [CrossRef] [PubMed]

38. Osman, Z.; Ibrahim, Z.A.; Arof, A.K. Conductivity enhancement due to ion dissociation in plasticized chitosan based polymer electrolytes. Carbohydr. Polym. 2001, 44, 167-173. [CrossRef]

39. Leones, R.; Sabadini, R.C.; Esperança, J.M.S.S.; Pawlicka, A.; Silva, M.M. Effect of storage time on the ionic conductivity of chitosan-solid polymer electrolytes incorporating cyano-based ionic liquids. Electrochim. Acta 2017, 232, 22-29. [CrossRef]

40. Ali, G.A.; Manaf, S.A.; Divyashree, A.; Chong, K.F.; Hegde, G. Superior supercapacitive performance in porous nanocarbons. J. Energy Chem. 2016, 25, 734-739. [CrossRef]

41. Ali, G.A.; Manaf, S.A.; Kumar, A.; Chong, K.F.; Hegde, G. High performance supercapacitor using catalysis free porous carbon nanoparticles. J. Phys. D Appl. Phys. 2014, 47, 495307. [CrossRef]

42. Fan, L.; Wang, M.; Zhang, Z.; Qin, G.; Hu, X.; Chen, Q. Preparation and characterization of PVA alkaline solid polymer electrolyte with addition of bamboo charcoal. Materials 2018, 11, 679. [CrossRef] [PubMed]

43. Rangasamy, V.S.; Thayumanasundaram, S.; Locquet, J.P. Solid polymer electrolytes with poly(vinyl alcohol) and piperidinium based ionic liquid for Li-ion batteries. Solid State Ion. 2019, 333, 76-82. [CrossRef]

44. Mobarak, N.N.; Ahmad, A.; Abdullah, M.P.; Ramli, N.; Rahman, M.Y.A. Conductivity enhancement via chemical modification of chitosan based green polymer electrolyte. Electrochim. Acta 2013, 92, 161-167. [CrossRef]

45. Aziz, S.B.; Abidin, Z.H.Z. Electrical Conduction Mechanism in Solid Polymer Electrolytes: New Concepts to Arrhenius Equation. J. Soft Matter 2013, 2013, 1-8. [CrossRef]

46. Hamsan, M.H.; Shukur, M.F.; Aziz, S.B.; Kadir, M.F.Z. Dextran from Leuconostocmesenteroides-doped ammonium salt-based green polymer electrolyte. Bull. Mater. Sci. 2019, 42, 42-57. [CrossRef]

47. Agrawal, P.; Strijkers, G.J.; Nicolay, K. Chitosan-based systems for molecular imaging. Adv. Drug Deliv. Rev. 2010, 62, 42-58. [CrossRef]

48. Aziz, S.B.; Mamand, S.M. The Study of dielectric properties and conductivity relaxation of ion conducting chitosan: NaTf based solid electrolyte. Int. J. Electrochem. Sci. 2018, 13, 10274-10288. [CrossRef]

49. Ramesh, S.; Ng, H.M.; Shanti, R.; Ramesh, K. Studies on the Influence of Titania Content on the Properties of Poly(vinyl chloride)—Poly (acrylonitrile)-Based Polymer Electrolytes. Polym. Plast. Technol. Eng. 2013, 52, 1474-1481. [CrossRef]

50. Zulkifli, A.M.; Said, N.I.; Aziz, S.B.; Hisham, S.; Shah, S.; Abu, A.; Bakar, Z.H.; Tajuddin, H.A.; Sulaiman, L.; Brza, M.A.; et al. Electrochemical Characteristics of Phthaloyl Chitosan Based Gel Polymer Electrolyte for Dye Sensitized Solar Cell Application. Int. J. Electrochem. Sci. 2020, 15, 7434-7447. [CrossRef]

51. Khiar, A.S.A.; Puteh, R.; Arof, A.K. Conductivity studies of a chitosan-based polymer electrolyte. Phys. B Condens. Matter 2006, 373, 23-27. [CrossRef]

52. Woo, H.J.; Majid, S.R.; Arof, A.K. Dielectric properties and morphology of polymer electrolyte based on poly( $\varepsilon$-caprolactone) and ammonium thiocyanate. Mater. Chem. Phys. 2012, 134, 755-761. [CrossRef] 
53. Abdullah, A.; Abdullah, S.Z.; Ali, A.M.M.; Winie, T.; Yahya, M.Z.A.; Subban, R.H.Y. Electrical properties of PEO-LiCF $\mathrm{SO}_{3}-\mathrm{SiO}_{2}$ nanocomposite polymer electrolytes. Mater. Res. Innov. 2009, 13, 255-258. [CrossRef]

54. Mustafa, M.S.; Ghareeb, H.O.; Aziz, S.B.; Brza, M.A.; Al-zangana, S.; Hadi, J.M.; Kadir, M.F.Z. Electrochemical characteristics of glycerolized PEO-based polymer electrolytes. Membranes 2020, 10, 116. [CrossRef] [PubMed]

55. Basha, S.K.S.; Sundari, G.S.; Kumar, K.V.; Rao, M.C. Preparation and dielectric properties of PVP-based polymer electrolyte films for solid-state battery application. Polym. Bull. 2018, 75, 925-945. [CrossRef]

56. Muhammed, D.S.; Brza, M.A.; Nofal, M.M.; Aziz, S.B.; Hussen, S.A.; Abdulwahid, R.T. Optical dielectric loss as a novel approach to specify the types of electron transition: XRD and UV-vis as a non-destructive techniques for structural and optical characterization of PEO based nanocomposites. Materials 2020, 13, 2979. [CrossRef]

57. Aziz, S.B.; Abidin, Z.H.Z. Electrical and morphological analysis of chitosan: AgTf solid electrolyte. Mater. Chem. Phys. 2014, 144, 280-286. [CrossRef]

58. Patel, G.B.; Singh, N.L.; Singh, F. Modification of chitosan-based biodegradable polymer by irradiation with MeV ions for electrolyte applications. Mater. Sci. Eng. B Solid State Mater. Adv. Technol. 2017, 225, 150-159. [CrossRef]

59. Hadi, J.M.; Aziz, S.B.; Mustafa, M.S.; Hamsan, M.H.; Abdulwahid, R.T.; Kadir, M.F.Z.; Ghareeb, H.O. Role of nano-capacitor on dielectric constant enhancement in PEO: $\mathrm{NH}_{4} \mathrm{SCN}: \mathrm{xCeO}_{2}$ polymer nano-composites: Electrical and electrochemical properties. J. Mater. Res. Technol. 2020, 9, 9283-9294. [CrossRef]

60. Marf, A.S.; Abdullah, R.M.; Aziz, S.B. Structural, morphological, electrical and electrochemical properties of PVA: CS-based proton-conducting polymer blend electrolytes. Membranes 2020, 10, 71. [CrossRef]

61. Hadi, J.M.; Aziz, S.B.; Nofal, M.M.; Hussen, S.A.; Hamsan, M.H.; Brza, M.A.; Abdulwahid, R.T.; Kadir, M.F.; Woo, H.J. Electrical, dielectric property and electrochemical performances of plasticized silver ion-conducting chitosan-based polymer nanocomposites. Membranes 2020, 10, 151. [CrossRef]

62. Okutan, M.; Şentürk, E. Dielectric relaxation mode in side-chain liquid crystalline polymer film. J. Non Cryst. Solids 2008, 354, 1526-1530. [CrossRef]

63. Aziz, S.B.; Abidin, Z.H.Z.; Arof, A.K. Influence of silver ion reduction on electrical modulus parameters of solid polymer electrolyte based on chitosan-silver triflate electrolyte membrane. Express Polym. Lett. 2010, 4, 300-310. [CrossRef]

64. Macedo, P.B.; Moynihan, C.T.; Bose, R. The Role of Ionic Diffusion in Polarization in Vitreous Ionic Conductors. Phys. Chem. Glasses 1972, 13, 171-179.

65. Pradhan, D.K.; Choudhary, R.N.P.; Samantaray, B.K. Studies of Dielectric Relaxation and AC Conductivity Behavior of Plasticized Polymer Nanocomposite Electrolytes. Int. J. Electrochem. Sci. 2008, 3, 597-608.

66. Aziz, S.B.; Abidin, Z.H.Z. Ion-transport study in nanocomposite solid polymer electrolytes based on chitosan: Electrical and dielectric analysis. J. Appl. Polym. Sci. 2015, 132, 1-10. [CrossRef]

67. Aziz, S.B. Role of Dielectric Constant on Ion Transport:Reformulated Arrhenius Equation. Adv. Mater. Sci. Eng. 2016. [CrossRef]

68. Aziz, S.B. Occurrence of electrical percolation threshold and observation of phase transition in $\operatorname{chitosan}_{(1-x)}$ : $\operatorname{AgI}_{x}(0.05 \leq x \leq 0.2)$-based ion-conducting solid polymer composites. Appl. Phys. A 2016, 122, 706. [CrossRef]

69. Kanchan, D.K.; Padmasree, K.P.; Panchal, H.R.; Kulkarni, A.R. Electrical transport studies on CdI2 doped silver oxysalt system. Ceram. Int. 2004, 30, 1655-1660. [CrossRef]

70. Aziz, S.B.; Abdullah, R.M. Crystalline and amorphous phase identification from the tan $\delta$ relaxation peaks and impedance plots in polymer blend electrolytes based on [CS: AgNt] x: PEO (x-1)(10 $\leq \mathrm{x} \leq 50)$. Electrochim. Acta 2018, 285, 30-46. [CrossRef]

71. Ayesh, A.S. Dielectric relaxation and thermal stability of polycarbonate doped with $\mathrm{MnCl}_{2}$ salt. J. Thermoplast. Compos. Mater. 2008, 21, 309-322. [CrossRef]

72. Aziz, S.B.; Abdullah, R.M.; Kadir, M.F.; Ahmed, H.M. Non suitability of silver ion conducting polymer electrolytes based on chitosan mediated by barium titanate $\left(\mathrm{BaTiO}_{3}\right)$ for electrochemical device applications. Electrochim. Acta 2019, 296, 494-507. [CrossRef]

73. Hamsan, M.H.; Aziz, S.B.; Nofal, M.M.; Brza, M.A.; Abdulwahid, R.T.; Hadi, J.M.; Karim, W.O.; Kadir, M.F. Characteristics of EDLC device fabricated from plasticized chitosan: $\mathrm{MgCl} 2$ based polymer electrolyte. J. Mater. Res. Technol. 2020, 9, 10635-10646. [CrossRef]

74. Polu, A.R.; Kumar, R. Preparation and characterization of PEG- $\mathrm{Mg}\left(\mathrm{CH}_{3} \mathrm{COO}\right)_{2}-\mathrm{CeO}_{2}$ composite polymer electrolytes for battery application. Bull. Mater. Sci. 2014, 37, 309-314. [CrossRef] 
75. Ramlli, M.A.; Isa, M.I.N. Structural and ionic transport properties of protonic conducting solid biopolymer electrolytes based on carboxymethyl cellulose doped with ammonium fluoride. J. Phys. Chem. B 2016, 120, 11567-11573. [CrossRef] [PubMed]

76. Shukur, M.F.; Ithnin, R.; Kadir, M.F.Z. Ionic conductivity and dielectric properties of potato starch-magnesium acetate biopolymer electrolytes: The effect of glycerol and 1-butyl-3-methylimidazolium chloride. Ionics 2016, 22, 1113-1123. [CrossRef]

77. Chai, M.N.; Isa, M.I.N. Novel Proton Conducting Solid Bio-polymer Electrolytes Based on Carboxymethyl Cellulose Doped with Oleic Acid and Plasticized with Glycerol. Sci. Rep. 2016, 6, 27328. [CrossRef]

78. Samsudin, A.S.; Lai, H.M.; Isa, M.I.N. Biopolymer materials based carboxymethyl cellulose as a proton conducting biopolymer electrolyte for application in rechargeable proton battery. Electrochim. Acta 2014, 129, 1-13. [CrossRef]

79. Sohaimy, M.I.H.; Isa, M.I.N. Ionic conductivity and conduction mechanism studies on cellulose based solid polymer electrolytes doped with ammonium carbonate. Polym. Bull. 2017, 74, 1371-1386. [CrossRef]

80. Shukur, M.F.; Hamsan, M.H.; Kadir, M.F.Z. Investigation of plasticized ionic conductor based on chitosan and ammonium bromide for EDLC application. Mater. Today Proc. 2019, 17, 490-498. [CrossRef]

81. Yusof, Y.M.; Shukur, M.F.; Hamsan, M.H.; Jumbri, K.; Kadir, M.F.Z. Plasticized solid polymer electrolyte based on natural polymer blend incorporated with lithium perchlorate for electrical double-layer capacitor fabrication. Ionics 2019, 25, 5473-5484. [CrossRef]

82. Aziz, S.B.; Hamsan, M.H.; Abdullah, R.M.; Kadir, M.F.Z. A promising polymer blend electrolytes based on chitosan: Methyl cellulose for EDLC application with high specific capacitance and energy density. Molecules 2019, 24, 2503. [CrossRef] [PubMed]

83. Pratap, R.; Singh, B.; Chandra, S. Polymeric rechargeable solid-state proton battery. J. Power Sources 2006, 161, 702-706. [CrossRef]

84. Yusof, Y.M.; Majid, N.A.; Kasmani, R.M.; Illias, H.A.; Kadir, M.F.Z. The Effect of Plasticization on Conductivity and Other Properties of Starch/Chitosan Blend Biopolymer Electrolyte Incorporated with Ammonium Iodide. Mol. Cryst. Liq. Cryst. 2014, 603, 73-88. [CrossRef]

85. Brza, M.A.; Aziz, S.B.; Nofal, M.M.; Saeed, S.R.; Al-Zangana, S.; Karim, W.O.; Hussen, S.A.; Abdulwahid, R.T.; Kadir, M.F. Drawbacks of low lattice energy ammonium salts for ion-conducting polymer electrolyte preparation: Structural, morphological and electrical characteristics of CS:PEO: $\mathrm{NH}_{4} \mathrm{BF}_{4}$-based polymer blend electrolytes. Polymers 2020, 12, 1885. [CrossRef] [PubMed]

86. Mishra, K.; Hashmi, S.A.; Rai, D.K. Studies on a proton battery using gel polymer electrolyte. High Perform. Polym. 2014, 26, 672-676. [CrossRef]

87. Heinze, J. Cyclic Voltammetry- “Electrochemical Spectroscopy”. New Analytical Methods (25). Angew. Chem. Int. Ed. Engl. 1984, 23, 831-847. [CrossRef]

88. Elgrishi, N.; Rountree, K.J.; McCarthy, B.D.; Rountree, E.S.; Eisenhart, T.T.; Dempsey, J.L. A Practical Beginner's Guide to Cyclic Voltammetry. J. Chem. Educ. 2018, 95, 197-206. [CrossRef]

89. Lim, C.S.; Teoh, K.H.; Liew, C.W.; Ramesh, S. Capacitive behavior studies on electrical double layer capacitor using poly (vinyl alcohol)-lithium perchlorate based polymer electrolyte incorporated with $\mathrm{TiO}_{2}$. Mater. Chem. Phys. 2014, 143, 661-667. [CrossRef]

90. Hegde, G.; Abdul Manaf, S.A.; Kumar, A.; Ali, G.A.M.; Chong, K.F.; Ngaini, Z.; Sharma, K.V. Biowaste Sago Bark Based Catalyst Free Carbon Nanospheres: Waste to Wealth Approach. ACS Sustain. Chem. Eng. 2015, 3, 2247-2253. [CrossRef]

91. Pal, B.; Yang, S.; Ramesh, S.; Thangadurai, V.; Jose, R. Electrolyte selection for supercapacitive devices: A critical review. Nanoscale Adv. 2019, 1,3807-3835. [CrossRef]

92. Aziz, S.B.; Brza, M.A.; Hamsan, H.M.; Kadir, M.F.Z.; Abdulwahid, R.T. Electrochemical characteristics of solid state double-layer capacitor constructed from proton conducting chitosan-based polymer blend electrolytes. Polym. Bull. 2020. [CrossRef]

93. Chong, M.Y.; Numan, A.; Liew, C.W.; Ng, H.M.; Ramesh, K.; Ramesh, S. Enhancing the performance of green solid-state electric double-layer capacitor incorporated with fumed silica nanoparticles. J. Phys. Chem. Solids 2018, 117, 194-203. [CrossRef]

94. Kasprzak, D.; Stẹpniak, I.; Galiński, M. Electrodes and hydrogel electrolytes based on cellulose: Fabrication and characterization as EDLC components. J. Solid State Electrochem. 2018, 22, 3035-3047. [CrossRef] 
95. Yang, C.C.; Wu, G.M. Study of microporous PVA/PVC composite polymer membrane and it application to $\mathrm{MnO}_{2}$ capacitors. Mater. Chem. Phys. 2009, 114, 948-955. [CrossRef]

96. Arof, A.K.; Shuhaimi, N.E.A.; Alias, N.A.; Kufian, M.Z.; Majid, S.R. Application of chitosan/iota-carrageenan polymer electrolytes in electrical double layer capacitor (EDLC). J. Solid State Electrochem. 2010, 14, 2145-2152. [CrossRef]

97. Aziz, S.B.; Brza, M.A.; Dannoun, E.M.A.; Hamsan, M.H.; Hadi,J.M. The Study of Electrical and Electrochemical Properties of Magnesium Ion Conducting CS: PVA Based Polymer Blend Electrolytes: Role of Lattice Energy of Magnesium Salts on EDLC Performance. Molecules 2020, 25, 4503. [CrossRef] [PubMed]

98. Asmara, S.N.; Kufian, M.Z.; Majid, S.R.; Arof, A.K. Preparation and characterization of magnesium ion gel polymer electrolytes for application in electrical double layer capacitors. Electrochim. Acta 2011, 57, 91-97. [CrossRef]

99. Nadiah, N.S.; Mahipal, Y.K.; Numan, A.; Ramesh, S.; Ramesh, K. Efficiency of supercapacitor using EC/DMC-based liquid electrolytes with methyl methacrylate (MMA) monomer. Ionics 2016, 22, 107-114. [CrossRef]

100. Aziz, S.B.; Hamsan, M.H.; Karim, W.O.; Marif, A.S.; Abdulwahid, R.T.; Kadir, M.F.Z.; Brza, M.A. Study of impedance and solid-state double-layer capacitor behavior of proton $\left(\mathrm{H}^{+}\right)$-conducting polymer blend electrolyte-based CS:PS polymers. Ionics 2020, 26, 4635-4649. [CrossRef]

101. Zainuddin, N.K.; Rasali, N.M.J.; Mazuki, N.F.; Saadiah, M.A.; Samsudin, A.S. Investigation on favourable ionic conduction based on CMC-K carrageenan proton conducting hybrid solid bio-polymer electrolytes for applications in EDLC. Int. J. Hydrogen Energy 2020, 45, 8727-8741. [CrossRef]

102. Hamsan, M.H.; Aziz, S.B.; Kadir, M.F.Z.; Brza, M.A.; Karim, W.O. The study of EDLC device fabricated from plasticized magnesium ion conducting chitosan based polymer electrolyte. Polym. Test. 2020, 90, 106714. [CrossRef]

103. Gu, H.B.; Kim, J.U.; Song, H.W.; Park, G.C.; Park, B.K. Electrochemical properties of carbon composite electrode with polymer electrolyte for electric double-layer capacitor. Electrochim. Acta 2000, 45, 1533-1536. [CrossRef]

104. Kamarudin, K.H.; Hassan, M.; Isa, M.I.N. Lightweight and flexible solid-state EDLC based on optimized CMC- $\mathrm{NH}_{4} \mathrm{NO}_{3}$ solid bio-polymer electrolyte. ASM Sci. J. 2018, 11, 29-36.

105. Aziz, S.B.; Hamsan, M.H.; Abdullah, R.M.; Abdulwahid, R.T.; Brza, M.A.; Marif, A.S.; Kadir, M.F.Z. Protonic EDLC cell based on chitosan (CS): Methylcellulose (MC) solid polymer blend electrolytes. Ionics 2020, 26, 1829-1840. [CrossRef]

106. Aziz, S.B.; Hamsan, M.H.; Karim, W.O.; Kadir, M.F.Z.; Brza, M.A.; Abdullah, O.G. High proton conducting polymer blend electrolytes based on chitosan: Dextran with constant specific capacitance and energy density. Biomolecules 2019, 9, 267. [CrossRef]

107. Muchakayala, R.; Song, S.; Wang, J.; Fan, Y.; Bengeppagari, M.; Chen, J.; Tan, M. Development and supercapacitor application of ionic liquid-incorporated gel polymer electrolyte films. J. Ind. Eng. Chem. 2018, 59, 79-89. [CrossRef]

108. Hamsan, M.H.; Shukur, M.F.; Aziz, S.B.; Yusof, Y.M.; Kadir, M.F.Z. Influence of NH 4 Br as an ionic source on the structural/electrical properties of dextran-based biopolymer electrolytes and EDLC application. Bull. Mater. Sci. 2020, 43. [CrossRef]

109. Yuhanees, M.Y. Characteristics of Corn Starch/Chitosan Blend Green Polymer Electrolytes Complexed with Ammonium Iodide and Its Application in Energy Devices. Ph.D. Thesis, University of Malaya, Kuala Lumpur, Malaysia, 2017.

110. Hamsan, M.H.; Shukur, M.F.; Kadir, M.F.Z. $\mathrm{NH}_{4} \mathrm{NO}_{3}$ as charge carrier contributor in glycerolized potato starch-methyl cellulose blend-based polymer electrolyte and the application in electrochemical double-layer capacitor. Ionics 2017, 23, 3429-3453. [CrossRef]

111. Aziz, S.B.; Hamsan, M.H.; Nofal, M.M.; Karim, W.O.; Brevik, I.; Brza, M.; Abdulwahid, R.T.; Al-Zangana, S.; Kadir, M.F.Z. Structural, impedance and electrochemical characteristics of electrical double layer capacitor devices based on Chitosan: Dextran biopolymer blend electrolytes. Polymers 2020, 12, 1411. [CrossRef]

112. Aziz, S.B.; Brza, M.A.; Brevik, I.; Hafiz, M.H.; Asnawi, A.S.; Yusof, Y.M.; Abdulwahid, R.T.; Kadir, M.F.Z. Blending and Characteristics of Electrochemical Double-Layer Capacitor Device Assembled from Plasticized Proton Ion Conducting Chitosan:Dextran:NH4PF6 Polymer Electrolytes. Polymers 2020, 12, 2103. [CrossRef] 
113. Wang, J.; Zhao, Z.; Song, S.; Ma, Q.; Liu, R. High performance poly(vinyl alcohol)-based Li-ion conducting gel polymer electrolyte films for electric double-layer capacitors. Polymers 2018, 10, 1179. [CrossRef] [PubMed]

114. Suleman, M.; Deraman, M.; Othman, M.A.; Omar, R.; Hashim, M.A.; Basri, N.H.; Nor, N.S.; Dolah, B.N.; Hanappi, M.F.; Hamdan, E.; et al. Electric double-layer capacitors with tea waste derived activated carbon electrodes and plastic crystal based flexible gel polymer electrolytes. J. Phys. Conf. Ser. 2016, 739. [CrossRef]

Publisher's Note: MDPI stays neutral with regard to jurisdictional claims in published maps and institutional affiliations.

(C) 2020 by the authors. Licensee MDPI, Basel, Switzerland. This article is an open access article distributed under the terms and conditions of the Creative Commons Attribution (CC BY) license (http://creativecommons.org/licenses/by/4.0/). 